\title{
Quantitative aspects of blood and amino acid flows in cattle
}

\author{
P Lescoat 1,2, D Sauvant 1, A Danfær 2 \\ 1 Laboratoire de nutrition et alimentation, Inra-Ina-PG, 16, rue Claude-Bernard, \\ 75231 Paris cedex 05, France; \\ 2 Danish Institute of Animal Science, Research Centre Foulum, PO Box 39, 8830 Tjele, Denmark
}

(Received 6 July 1995; accepted 12 January 1996)

\begin{abstract}
Summary - A quantitative literature review was undertaken on the amino acid fluxes in ruminants and the factors which influence them. Two aspects were considered: blood flow and amino acid uptake by tissues. The statistical relationships indicated that blood flow was influenced by feed intake, metabolizable energy and milk production. The rates of amino acid uptake and release by tissues and organs varied greatly between compartments and between amino acids. The net rates of appearance were the result of a combination of inter- and intratissue phenomena. Simulated balances between supply and requirements revealed the limiting role of certain amino acids, depending on milk production level and growth rate. In conclusion, this approach underlined the technical difficulties involved in obtaining this type of data, and also revealed a lack of data in certains areas. Nevertheless, the observations in this review supported the implementation of the feed units used at the present time, notably for the addition of amino acids.
\end{abstract}

\section{amino acid / ruminant / blood flow / statistical analysis}

Résumé - Aspects quantitatifs des débits sanguins et des flux nets d'acides aminés chez le ruminant. Une revue bibliographique a été faite sur les flux d'acides aminés chez les ruminants et leurs déterminants. Deux aspects ont été étudiés : les débits sanguins et les captations d'acides aminés par les tissus. Des relations statistiques calculées montrent les variations importantes des flux sanguins en fonction des niveaux d'ingestion d'aliment, d'énergie ou de production laitière. Les taux de captation et largages d'acides aminés par les tissus et organes varient fortement d'un compartiment et d'un acide aminé à l'autre. Ces taux nets sont des résumés de l'ensemble des phénomènes intra et intertissus. Des simulations des bilans apports-besoins montrent le rôle limitant de certains acides aminés en fonction des niveaux de production laitiere ou de croissance. Finalement, cette approche a souligné les difficultés techniques d'obtenir des données, voire leurs absences dans certaines situations. Néanmoins, les observations de ce travail sont en accord avec le développement des systèmes d'unités d'alimentation actuels, notamment dans leur ajout des acides aminés. 


\section{INTRODUCTION}

Significant progress has been made during the last ten years in the area of applied ruminant protein nutrition thanks to the development of new unit systems (Vérité and Peyraud, 1989; Hvelplund and Madsen, 1990; Tamminga et al, 1994). In these systems, the efficiency of absorbed amino acids for milk protein synthesis is assumed to be constant for a given type of animal although Vérité and Peyraud (1989) have provided evidence for a non-linear relationship between PDI (true digestible protein in the intestine) supply and milk production in dairy cows. Recently, the problem of protein nutrition in lactating ruminants was complicated by the discovery of the limiting role of some amino acids, namely methionine and lysine (eg, Rulquin, 1987). To take this into account, Rulquin et al (1993) have designed a new version of the PDI system, integrating the curvilinear response of milk protein content and production to the supplies of these two amino acids. Despite this progress, large areas of uncertainty remain concerning the metabolic aspects of amino acid utilization: their use in relation to energy metabolism and the interactions between amino acids. These aspects could for example result in several amino acids becoming limiting from a dynamic point of view: they are in the body but not available for the tissue in question (Meijer et al, 1995).

To overcome this lack of knowledge, it appeared necessary to integrate the literature data and use modelling to analyse the knowledge of the major underlying quantitative aspects of amino acid metabolism, particularly at the level of key organs. Mechanistic models for the lactating cow have already been created (Baldwin et al, 1987; Danfaer, 1990). These models, however, are not appropriate in the light of present dogma because they assume the existence of only one aggregated pool of amino acids in the intermediary metabolism. They do not, therefore, allow the resolution of the above-mentioned uncertainties. During the last decades, a large number of experiments have been carried out to quantitate amino acids flows. The aim of this work was to pool and analyse this previously published data. Moreover, as the variation in blood flow plays a key role in the determination of the amino acid partition and exchange between organs, it was decided to dedicate part of this work to its prediction from simple zootechnical parameters.

\section{METHOD}

The current work was divided into several steps to analyse the collected information. First of all, articles dealing with ruminant, amino acid and protein intermediary metabolism as key-words were taken from the literature. Secondly, quantitative results (amino acid uptake, blood flow, etc) and associated factors (experimental design, factor tested, etc) or variables (body weight, dry matter intake, milk production level, etc) were collected and put together to constitute a data base. Each of these collected results was called an 'observation'. An observation was usually a treatment mean from cited work. As such, individual animals could influence more than one observation, especially when Latin square or crossover designs were used by the original investigators. Thirdly, all the observations were treated with statistical tools following several steps. The first one consisted of studying the homogeneity of the data set and in discarding observations which were largely out of an accepted range from either a biological or a statistical point of view. The biological basis was based on the fact that this study was mainly calibrated for lactating cows and growing cattle; consequently, data on new-born ruminants or in vitro experiments were excluded. For the latter aspect, the statistical range limit was set at two standard deviations from the mean obtained after an analysis of variance. The second step was to test different empirical models between the collected factors and variables, and the third was to discuss the validity of the calculated relationships.

The statistical package used was SAS (SAS, 1987 ) with the NLIN or GLM procedures. The models and statistical tools used for each data set are further described in the corresponding part of this text. To evaluate the consistency of the 
statistical models found for each aspect and tissue, they were all integrated into a static empirical model of amino acid flows and partitioned in the intermediary metabolism either of lactating cows or growing cattle.

\section{TISSUE BLOOD FLOWS}

As mentioned earlier, the goal of this review was to obtain the most accurate prediction possible of blood flows through the major organs from animal production parameters.

\section{Blood flow through the splanchnic tissues}

Observations were taken from 28 publications concerning growing steers, heifers or cows to build a file of 120 observations (Baird et al, 1975; Casse et al, 1994; Early et al, 1987; Eisemann and Huntington, 1994; Eisemann and Nienaber, 1990; Gross et al, 1988; Guerino et al, 1991; Hammond et al, 1987; Harmon et al, 1988, 1993; Huntington, 1982, 1984, 1987; Huntington and Prior, 1983; Huntington et al, 1983, 1988, 1990; Krehbiel et al, 1992; Kreikemeier et al, 1991; Lomax and Baird, 1983; McGuire et al, 1989; Prior et al, 1981; Reynolds and Huntington, 1988; Reynolds and Tyrrell, 1991; Reynolds et al, 1988, 1991, 1992; Wieghart et al, 1986). In the available data set, the method of blood flow measurement was systematically the
PAH dilution technique of Katz and Bergman (1969), which was sometimes modified. Different blood flow measurement methods, such as the ultrasonic flow probe, are used in small animals. However, this technique does not yet give consistent results in large ruminants for portal blood flow (Huntington et al, 1990). Animal weight (W, kg), dry matter intake (DMl, kg/day), digestible (DEl, MJ/day) and metabolizable (MEI, MJ/day) energy intake, portal (PBF, L/day) and hepatic (HBF, L/day) blood flows, number of meals per day and duration of fasting were noted. A summary of the data set revealed that a wide range of animals and intake levels were taken into account (table I).

The dependent variables were PBF, HBF, PBF and HBF divided by the metabolic weight (to give PM and HM respectively, $\mathrm{L} /$ day $/ \mathrm{kg}^{0.75}$ ). The independent variables were W, DMI, DEI, MEI and MEI divided by the metabolic weight (MEM, kJ/day $/ \mathrm{kg}^{0.75}$ ). The models tested were global linear and quadratic relations between independent and dependent variables. The influence of the experimental factor was not tested. This decision was taken because the experiments were not primarily designed to study blood flow but rather the net appearance of nutrients in the blood stream, and in most cases there was no specific experimental effect on blood flow. Only the most relevant adjustments are presented (table II). The statistical discrimination between the models was based mainly on the observation of resid-

Table I. Statistical summary of the data set on portal and hepatic blood flows.

\begin{tabular}{lcccc}
\hline Variable (unit) & $\mathrm{n}$ & Mean & Standard deviation & Range \\
\hline & & & & \\
Weight (kg) & 108 & 391.4 & 89 & $165-651$ \\
Dry matter intake (kg/day) & 103 & 7.50 & 10.17 & $1.93-21.8$ \\
Digestible energy intake (MJ/day) & 24 & 98.51 & 62.07 & $28.45-257.2$ \\
Metabolizable energy intake (MJ/day) & 70 & 79.04 & 43.88 & $25.02-231.5$ \\
Portal blood flow (L/d) & 120 & 19564 & 7483 & $8064-47808$ \\
Hepatic blood flow (L/d) & 65 & 22693 & 10889 & $9605-60576$
\end{tabular}


ual patterns by plotting the observed minus the estimated data on the $y$-axis and the independent variable on the $x$-axis.

PBF and HBF were linearly related to MEI, $\mathrm{DEI}$ and DMI. The models involving $\mathrm{MEI}$ in table II are in agreement with those found by Ortigues (1991) and the PBF regression with $\mathrm{DEl}$ is also in agreement with Wieghart et al (1986). Interestingly, these flows could also be fitted with S-shaped curves (Moore, 1985). These have a small increasing slope when the animal is severely underfed and a reduced slope compared with the prediction by the linear model for high level of intake. None of these models, however, proved to be better than the others, because of the lack of data for high feed intake levels. This stressed the lack of quantitative information concerning high blood flows, which is necessary to discriminate between models describing decreasing marginal increases for high portal and hepatic flows.

PBF was linearly correlated to $W$. In addition, HBF was statistically positively correlated to both $W$ and DMI. PM (fig 1A) and HM (fig 1B) were linearly correlated to MEM. These four adjustments underline the importance of animal weight and, on the home- orhetic side (Sauvant, 1994), the level of energy intake which increased hepatic and portal blood flows. The best predictor might be MEl (Reynolds et al, 1994a). However, measurements of MEI values are seldom published and their calculation from publications necessitates certain assumptions. Thus, the equations including DMI, which is more accurately determined than $\mathrm{MEI}$, were also proposed for a practical purpose. The number of meals per day did not significantly influence the blood flow. This could be explained by the fact that most of the observations were mean values over an experimental period. If the animals were fed twice a day the authors observed a transitory increase in PBF after the meal (Mineo et al, 1991), and to reduce this effect the ration was generally given in numerous meals, such as every hour.

There was a close linear relation between $\mathrm{HBF}$ and PBF, only valid for HBF greater than PBF:

$$
\begin{aligned}
& \text { PBF (L/day) }=1453.5(540)+0.7382 \\
& (0.0226)^{\star} \mathrm{HBF}(\mathrm{L} / \text { day }) \\
& n=51, \mathrm{R}^{2}=0.96, \mathrm{RSD}=1607.5 \\
& \text { PBF accounted for an average of } 81.8 \% \\
& \text { of HBF with a standard deviation of } 6.85 \% \text {. }
\end{aligned}
$$

\begin{tabular}{|c|c|c|c|c|}
\hline Variable (unit) & $\mathrm{n}$ & Model $\mathrm{b}$ & $R S D$ & $\mathrm{R}^{2}$ \\
\hline HBF (L/day) & 47 & $4216(1039)+207.5(10.3) \times \mathrm{MEI}$ & 3548 & 0.90 \\
\hline HBF (L/day) & 18 & $7330(2184)+161.3(17.2) \times \mathrm{DEI}$ & 4841 & 0.85 \\
\hline HBF (L/day) & 34 & $5951(1427)+2253(163.7) \times \mathrm{DMI}$ & 4167 & 0.86 \\
\hline HBF (L/day) & 32 & $307(2565)+22.4(9) * W+1837(224) \times \mathrm{DMI}$ & 3858 & 0.89 \\
\hline PBF (L/day) & 70 & $6115(680)+151(7.5) \times \mathrm{MEI}$ & 2744 & 0.86 \\
\hline PBF (L/day) & 24 & $7674(1379)+119(11.9) \times \mathrm{DEI}$ & 3547 & 0.82 \\
\hline PBF (L/day) & 89 & $9441(1034)+1452(127) \times \mathrm{DMl}$ & 4522 & 0.60 \\
\hline PBF (L/day) & 94 & $815(2587)+47.7(6.5) \times W$ & 5735 & 0.37 \\
\hline $\mathrm{HM}\left(\mathrm{L} / \mathrm{day} / \mathrm{kg}^{0.75}\right)$ & 47 & $64.2(13.5)+0.190(0.013) \times$ MEM & 35.5 & 0.82 \\
\hline PM (L/day/kg 0.75$)$ & 70 & $83.7(10.5)+0.138(0.011) \times$ MEM & 32.5 & 0.70 \\
\hline
\end{tabular}

Table II. Statistical models describing the hepatic and portal blood flows a.

a HBF: hepatic vein blood flow, PBF: portal vein blood flow, PM: PBF divided by the metabolic weight, HM: HBF divided by the metabolic weight, MEl: metabolizable energy intake (MJ/day) DMI: dry matter intake (kg/g), W: animal weight (kg), MEM: MEI divided by the metabolic weight. ${ }^{b}$ The standard errors of the parameters are given in brackets. 
It must be emphasized that this ratio varied greatly and further experiments should be undertaken to explain these variations, which may have physiological implications. As the authors took into account the fact that HBF is the sum of PBF and hepatic artery blood flow, they could therefore cal- culate the hepatic artery blood flow. Due to errors associated with measurements, however, 'negative' hepatic artery fluxes could be obtained (Isserty and Ortigues, 1994). This demonstrates the need to understand the variations in the hepatic/portal veins ratio. On a daily basis it was possible to pre-
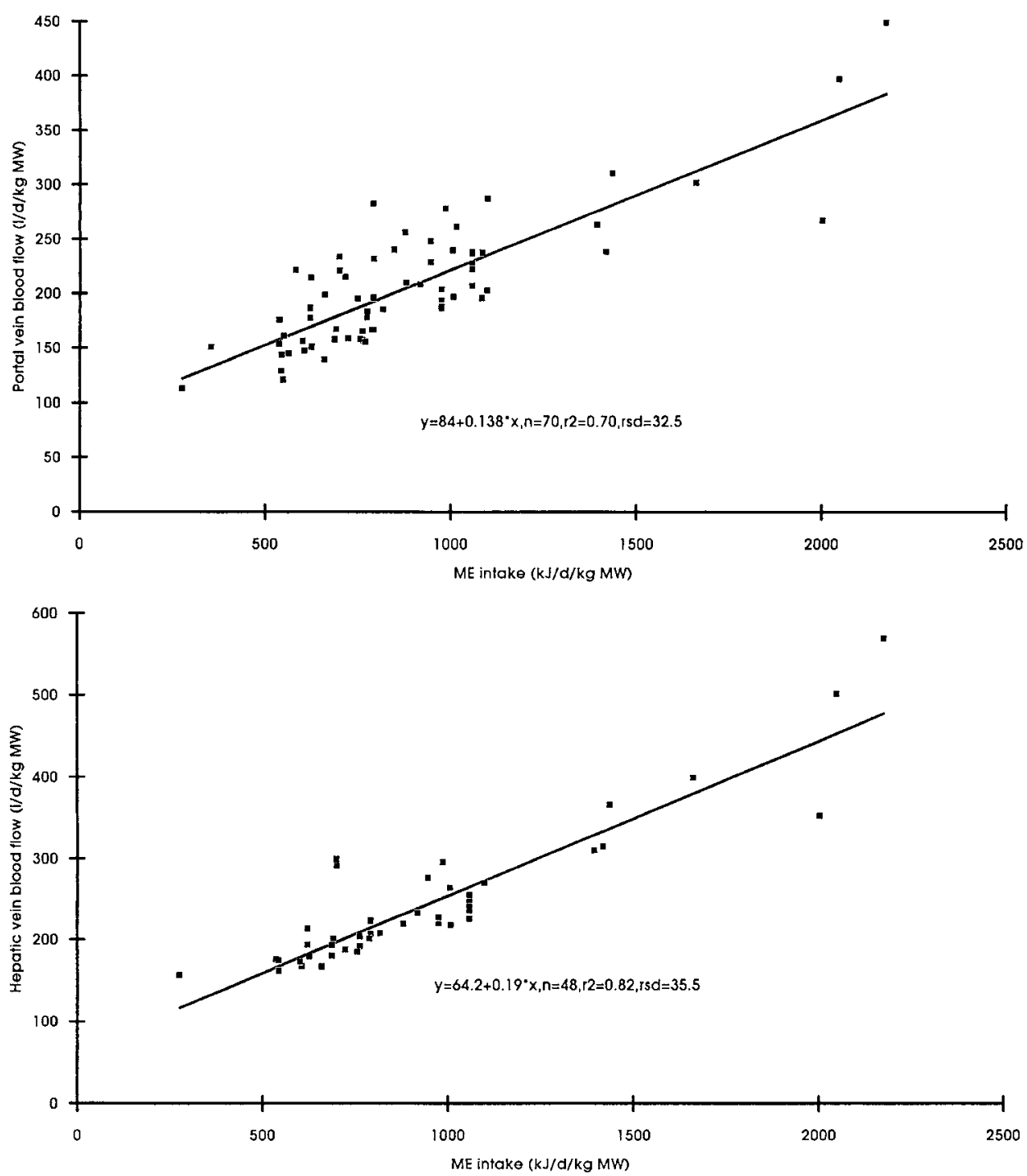

Fig 1. A. Relation between portal blood flow and ME intake per $\mathrm{kg}$ metabolic weight. B. Relation between hepatic blood flow and ME intake per $\mathrm{kg}$ metabolic weight. 
dict the amount of blood irrigating the splanchnic organs. More information is needed for high levels of feed intake, however, in order to clearly discriminate between the models proposed in table II and to determine the pattern of blood flow increase with high energy intakes.

\section{Muscle}

Muscle constitutes the largest protein compartment in the organism (Smith and Baldwin, 1974). Muscle blood flow has to be estimated because it is an intermediate parameter in the calculation of quantitative uptake and release of blood amino acids and peptides by this tissue (Danilson et al, 1987a, 1987b). However, data determining the factors influencing muscle blood flow remain scarce and are limited to growing ruminants ranging from $12-550 \mathrm{~kg}$ live weight. Moreover, the usual biological model of muscular mass is the hindlimb, which is a mixture of muscle $(61.5 \%)$, bone (18.5\%), skin $(7.4 \%)$, connective tissues $(9.9 \%)$ and fat $(2.5 \%)$ as observed in steers by Boisclair et al (1993b).

A set of 111 observations was collected from 23 publications concerning young ruminants (Brown et al, 1991; Crompton and Lomax, 1993; Oddy et al, 1987), sheep (Brid et al, 1981; Early et al, 1988; Heitmann et al, 1986; Oddy et al, 1981; Pethick and Verneau, 1984; Pethick et al, 1981, 1987; Symonds et al, 1988; Symonds and Lomax, 1990; Teleni and Annison, 1986; Teleni et al, 1986) and growing cattle (Bell et al, 1975; Boisclair et al, 1993a, 1994; Early et al, 1987; Eisemann et al, 1987, 1988; Eisemann and Nienaber, 1990; Eisemann and Huntington, 1994; Huntington and Prior, 1985). In each experiment, the information collected was the live weight $(\mathrm{W}, \mathrm{kg})$, dry matter intake (DMl, $g$ /day), type of animal, method of blood flow measurement, the catheterized vessels and other specific experimental factors. Methodological features were used to esti- mate the proportion of muscle in the hindlimbs taken into account and corrections were made based on pertinent guesses. The blood flow finally obtained was for the two hindlimbs together. These guesses increased the amount of variation observed.

Two expressions of muscle blood flow were given, depending on the method used: an absolute blood flow (AMuBF, L/day), which was mainly determined by dye dilution or an ultrasonic flow probe, and a relative blood flow (RMuBF, L/day/kg hindlimb) obtained with the diffusion equilibrium technique (Oddy et al, 1981) (table III). It was difficult to link these two expressions because the quantity of muscle considered in the AMuBF needed to be known to calculate RMuBF. AMuBF increased with animal weight. A highly significant linear relationship linked the natural logarithm of the animal's metabolic weight and the natural logarithm of AMuBF:

$$
\begin{aligned}
& \operatorname{LN}(\text { AMuBF }(\text { L/day }))=1.94(0.45)+1.547 \\
& (0.122) \times \operatorname{LN}\left(\mathrm{NW}\left(\mathrm{kg}^{0.75}\right)\right) \\
& n=56, R^{2}=0.75, \mathrm{RSD}=0.71
\end{aligned}
$$

Figure 2 shows the absolute hindlimb blood flow versus the metabolic weight according to the above equation. Logarithms were used to maintain equal residuals due to the large variations in AMuBF for animals of the same weight. A reason for these variations could be the different methods used for blood flow measurements and the catheter position (Teleni and Annison, 1986; Boisclair et al, 1993b). The catheter position determines which vessels will be taken into account and consequently the volume of hindlimb irrigated. Experimental factors can partially explain these variations, even though no statistical effect was significant due to the large between-experiment differences.

The quantity of feed and the protein content seemed to influence AMuBF, when the different means were compared graphically by treatment. Fasting or underfeeding reduced AMuBF by more than $50 \%$ (Bois- 
Table III. Statistical summary of the data set on hindlimb blood flow.

\begin{tabular}{|c|c|c|c|c|}
\hline Variable (unit) & $\mathbf{n}$ & Mean & Standard deviation & Range \\
\hline Live weight (kg) & 111 & 125.2 & 140.8 & $12-550$ \\
\hline Dry matter intake (kg/day) & 80 & 2.3 & 2.8 & $0-11$ \\
\hline Absolute blood flow (L/day) & 56 & 3998 & 3961 & $202-16128$ \\
\hline Relative blood flow (L/day/kg tissue) & 55 & 195.1 & 98.2 & $74.2-419$ \\
\hline
\end{tabular}

clair et al, 1993a; Early et al, 1987) or had no effect (Bell et al, 1975), although the length of the fasting period was short in the experiment of Bell et al (1975). Furthermore, RMUBF slightly decreased with progressive underfeeding in young lambs (Crompton and Lomax, 1993) but not in fasted lambs (Oddy et al, 1987; Symonds and Lomax, 1990; Teleni et al, 1986). To illustrate the lack of clarity in the influence of fasting on muscle blood flow, statistical regressions between DMI divided by animal metabolic weight and AMuBF also divided by metabolic weight showed no significant relationship.
Treatment with $\beta$-agonists strongly increased AMuBF (Eisemann et al, 1988; Brown et al, 1991) while bovine somatotropin had no effect (Boisclair et al, 1994). Supplies of insulin parenterally (AMuBF: Huntington and Prior, 1985) or locally (RMuBF: Oddy et al, 1987) increased the muscle blood flow. This could be related to a higher muscle anabolism, even if no response was noted with bovine somatotropin. A major influential factor on AMuBF (Bird et al, 1981) and RMuBF (Pethick et al, 1987) was the level of exercise, which could cause the blood flows to be multiplied by at least three. Moreover, Isserty and Ortigues (1994) have

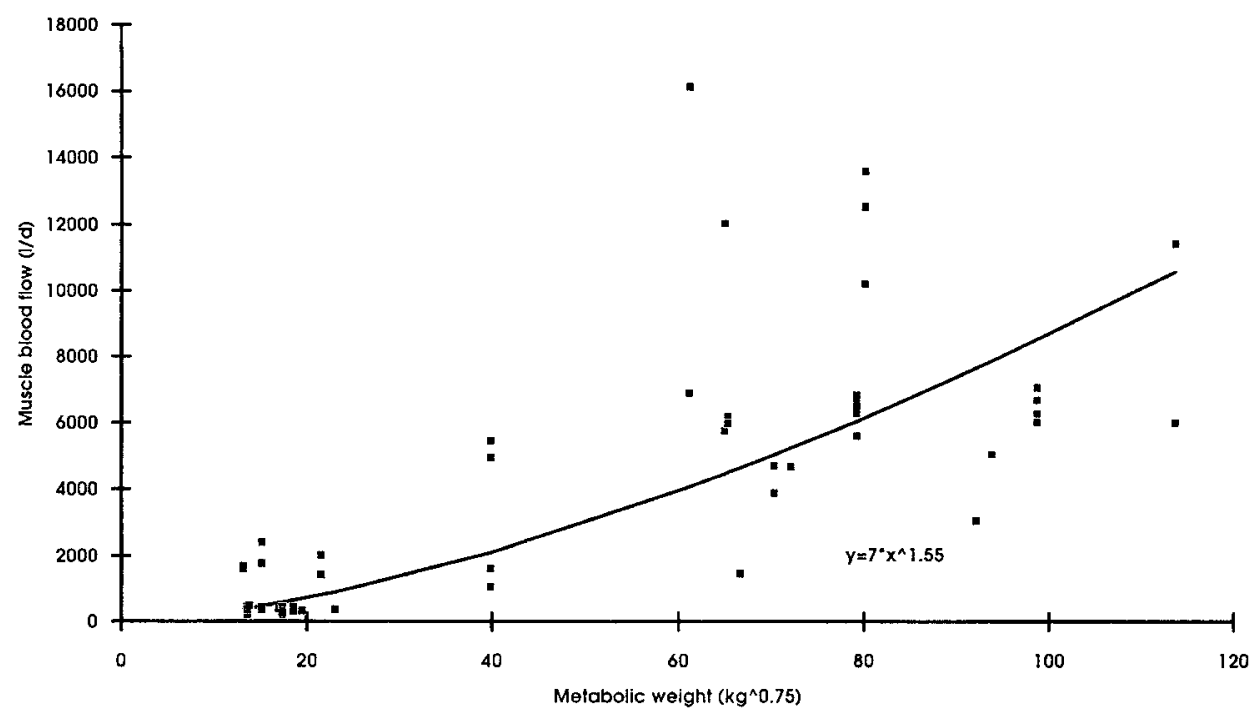

Fig 2. Relation between muscle blood flow and metabolic weight. 
demonstrated on six ewes that $77 \%$ of the outliers discarded from their final analyses were linked to animal movement.

More quantitative information is needed in order to be able to accurately predict muscle blood flow and exchange, and it must be emphasized that no data are available for either lactating ruminants or for the influence of different physiological states on blood flows. Some effects are known, such as hormones or exercise, but except for $\beta$ agonists they are not quantified (Eisemann et al, 1988; Brown et al, 1991), even if large differences have been observed in the hindlimb in connection with quantitative factors such as protein intake. To conclude, the large variations suggest that it would be interesting to tabulate the hindlimb blood flow according to the species and the physiological state, both in homeorhetic and homeostatic situations.

The hindlimb blood flow represents only part of the total whole body muscle blood flow. The muscle tissue represents $240 \mathrm{~kg}$ in a cow of $600 \mathrm{~kg}$ live weight (Riis, 1983). If the hindlimb fresh weight is $100 \mathrm{~kg}$, its muscle weight is $60 \mathrm{~kg}$. With the assumption of an equivalent irrigation of whole body muscle, the hindlimb blood flow represents $25 \%$ of the total muscle blood flow. Due to the lack of precision in this blood flow measurement, a constant blood flow should be taken for a given body weight according to the first equation in this section and should be multiplied by 4 to obtain the whole body muscle blood flow.

\section{Mammary gland}

Mammary gland blood flows (MaBF, L/day) have been measured for many years. Kronfeld et al (1968) proposed a linear regression between MaBF estimated by the antipyrine absorption method (Rasmussen, 1965 ) and milk production with a slope of $605 \mathrm{~L}$ blood to $1 \mathrm{~L}$ milk based on the results of one experiment. This regression was widely accepted and was even used to estimate the MaBF (Derrig et al, 1974; Munneke et al, 1991; Yang et al, 1986) although Reynolds et al (1968) demonstrated that the method gave an overestimation of the actual blood flow. Linzell (1974) also showed a positive linear relationship between milk production and MaBF, with a mean ratio of $500 \mathrm{~L}$ blood to $1 \mathrm{~L}$ milk in goats. However, he underlined the fact that this value was an approximation and that it could change inversely with the milk production level.

A data set of 11 publications on cows (Annison et al, 1974; Bickerstaffe et al, 1974; Cant et al, 1993; Davis et al, 1988; Guinard et al, 1994; Hartmann and Kronfeld, 1973; Kensinger et al, 1983; Kronfeld et al, 1968; Lough et al, 1990; Metcalf et al, 1991; Peeters et al, 1979) was collected. This data base contained 57 observations. The qualitative variables were the method of mammary blood flow measurement and the experimental factors, which were mainly tests on the uptake of nutrients by the mammary gland depending on the diet or infusion either in the duodenum or in the blood. The quantitative independent variables were body weight $(\mathrm{W}, \mathrm{kg}$ ), raw milk production (MPL, Lday), milk fat content (FC, $g / L$ ), milk protein content (PC, g/L), milk lactose content (LC, $\mathrm{g} / \mathrm{L}$ ), MaBF (L/day) and the stage of lactation (SL, week). A statistical summary of the data set is presented in table IV.

MaBF increased with MPL. A good fit between MaBF and MLP was obtained. These relations were consistent with those proposed by Linzell (1974) for goats. A logical lower limit different from zero appeared for MaBF during the dry period. Moreover, an upper limit seemed to appear for high MPL (fig 3). Several models were adjusted to the data set between MaBF and MPL (table V). Statistically the models were nearly equivalent, however their physiological bases were different. Linearity implied a constant increase of MaBF with MPL. This meant that high producing cows would have 
very high MaBF, difficult to attain and energy consuming. A quadratic relationship provided the best coefficent of determination for cows producing in the range of the data set, from 0-29.5 L/day. Nevertheless, this model was rejected because it gave decreasing MaBF for cows producing more than $29 \mathrm{~L}$ day. The three other models could not be statistically discriminated from each other. Nevertheless, they could be com- pared from a physiological point of view. The logarithmic model, LN, had the weakest coefficient of determination. However, it gave interesting MaBF estimates for the usual range of milk production and avoided the assumption of an upper limit for MaBF. The two exponential models EXP1 and EXP2 differed in their hypotheses concerning maximum MaBF. EXP1 was fitted by fixing the intercept at $1500 \mathrm{~L} /$ day and EXP2

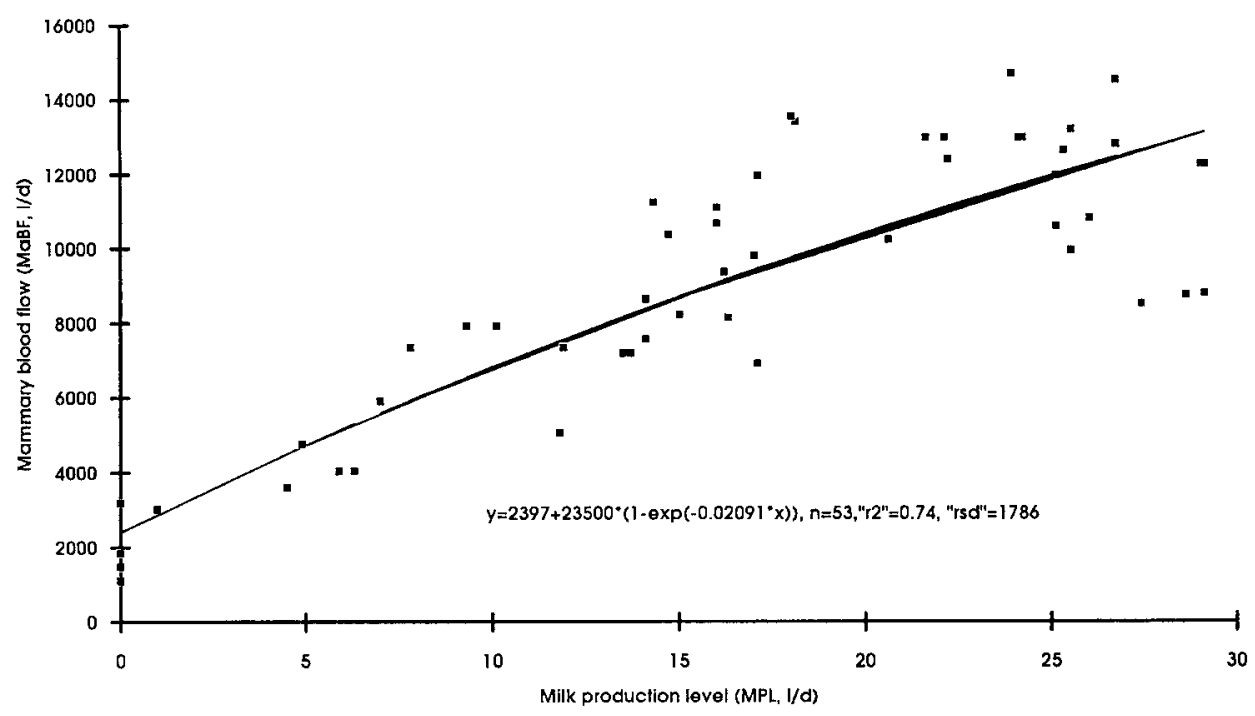

Fig 3. Relationship between mammary blood flow and milk production level.

Table IV. Statistical summary of the data set on mammary blood flow.

\begin{tabular}{lcccc}
\hline Variable (unit) & $\mathrm{n}$ & Mean & Standard deviation & Range \\
\hline & & & & \\
Weight (kg) & 29 & 470 & 79 & $350-650$ \\
Raw milk production (L/day) & 57 & 17.25 & 8.7 & $0-29.1$ \\
Milk fat content $(\mathrm{g} / \mathrm{L})$ & 26 & 36.7 & 9.4 & $9.6-50.3$ \\
Milk protein content (g/L) & 28 & 32.1 & 3.7 & $27.2-43.4$ \\
Milk lactose content (g/L) & 29 & 47.1 & 3.4 & $32.7-50.6$ \\
Mammary blood flow (L/day) & 57 & 9867 & 4718 & $1094-22507$ \\
Stage of lactation (week) & 39 & 12.5 & 7.5 & $2-38$ \\
& & & & \\
\hline
\end{tabular}


Table V. Statistical adjustments of MaBF by MPL a.

\begin{tabular}{lcccc} 
Name & $\mathrm{n}$ & Modeld & $R S D$ & $\mathrm{R}^{2}$ \\
\hline Linear & 53 & $3226.7(591.7)+348.7(31.7) \times \mathrm{MPL}$ & 1980 & 0.70 \\
Quadratic & 53 & $1416.3(707)+719.1(101) \times \mathrm{MPL}-12.4(3.25) \times \mathrm{MPL}^{2}$ & 1759 & 0.77 \\
LN & 53 & $434.1(834)+3276.9(301) \times \mathrm{LN}(1+\mathrm{MPL})$ & 1994 & 0.70 \\
EXP1b,c & 53 & $1500(-)+13162(1872) \times(1-\exp -0.05894(0.0161) \times \mathrm{MPL})$ & 1786 & 0.76 \\
EXP2b,c & 53 & $2397(651)+23500(-) \times\left(1-\exp ^{-0.02091(0.0024) \times \mathrm{MPL}}\right.$ & 1868 & 0.74
\end{tabular}

a MaBF: mammary blood flow (L/day) MPL: milk production level (l/d). $b$ For EXP1, 1550 is fixed before the iterations and 13162 and 0.05894 are fitted. For EXP2, 23500 is fixed before the iterations and 2397 and 0.02091 are fitted. c The RSD and $R^{2}$ of the exponential models are calculated via the proc GLM with the model statement: MaBF observed $=$ MaBF predicted by the exponential models. $d$ The standard errors of the parameters are given in brackets.

was fitted by fixing the distance from the intercept to the maximum value at 23500 Lday. EXP2 was calculated because EXP1 only allowed $14710 \mathrm{~L}$ day as a maximum blood flow, which seemed too low. Unfortunately, as shown by figure 3, no data on high-producing dairy cows was found. Some further MaBF measurements on cows producing $35-50 \mathrm{~L}$ of milk dairy would help to discriminate between these proposed empirical models.

As for the hepatic blood flow, the Sshaped model could be adjusted with MPL as an independent variable. MaBF was also closely related to milk protein and lactose production, however no improvement appeared when compared with the regression on MPL, due to the lack of precision in the measurement of the protein and lactose concentrations in our data set. These results need to be confirmed because milk protein, and especially milk lactose, concentrations are relatively constant and their synthesis is linked to a high nutrient transfer between the blood and milk. The milk fat production showed only a weak relationship with MaBF.

A few data (Cant et al, 1993) have been excluded from the statistical analysis because they were outside the limit of twice the standard deviation from the MaBF of the cows with an equivalent MPL. This exclusion revealed that the estimation of MaBF was very dependent on the method used. An analysis of covariance was performed with the following model on the other cow MaBF measurements:

$$
\begin{aligned}
& \mathrm{MaBF}_{\mathrm{ijk}}=\alpha+\beta \times \mathrm{MPL}_{\mathrm{i}}+(\text { Method })_{j}+\varepsilon_{\mathrm{ijk}} \\
& n=53, R^{2}=0.83, \mathrm{RSD}=1562
\end{aligned}
$$

There was a significant ranking between the methods used. The highest estimate was with the antipyrine absorption method (reference value set to zero, $n=19$ ), followed by the electromagnetic flow probe ( -977 L/day, $n=16$ ), continuous thermodilution technique (-2 $973 \mathrm{~L} / \mathrm{day}, n=14)$ and $\mathrm{PAH}$ dilution technique $(-4276 \mathrm{~L} /$ day, $n=$ 4). These results are in agreement with those of Reynolds et al (1968) for goats and Waghorn and Baldwin (1984) in a model of the lactating cow mammary gland for the overestimation of MaBF by the antipyrine absorption technique. Differences also appeared between the electromagnetic and continuous thermodilution techniques in our analysis.

There was a linear regression between MPL and the ratio MaBF/MPL (fig 4). The low producing cows (less than $1.5 \mathrm{~L}$ per day) were excluded from the statistical fitting, 


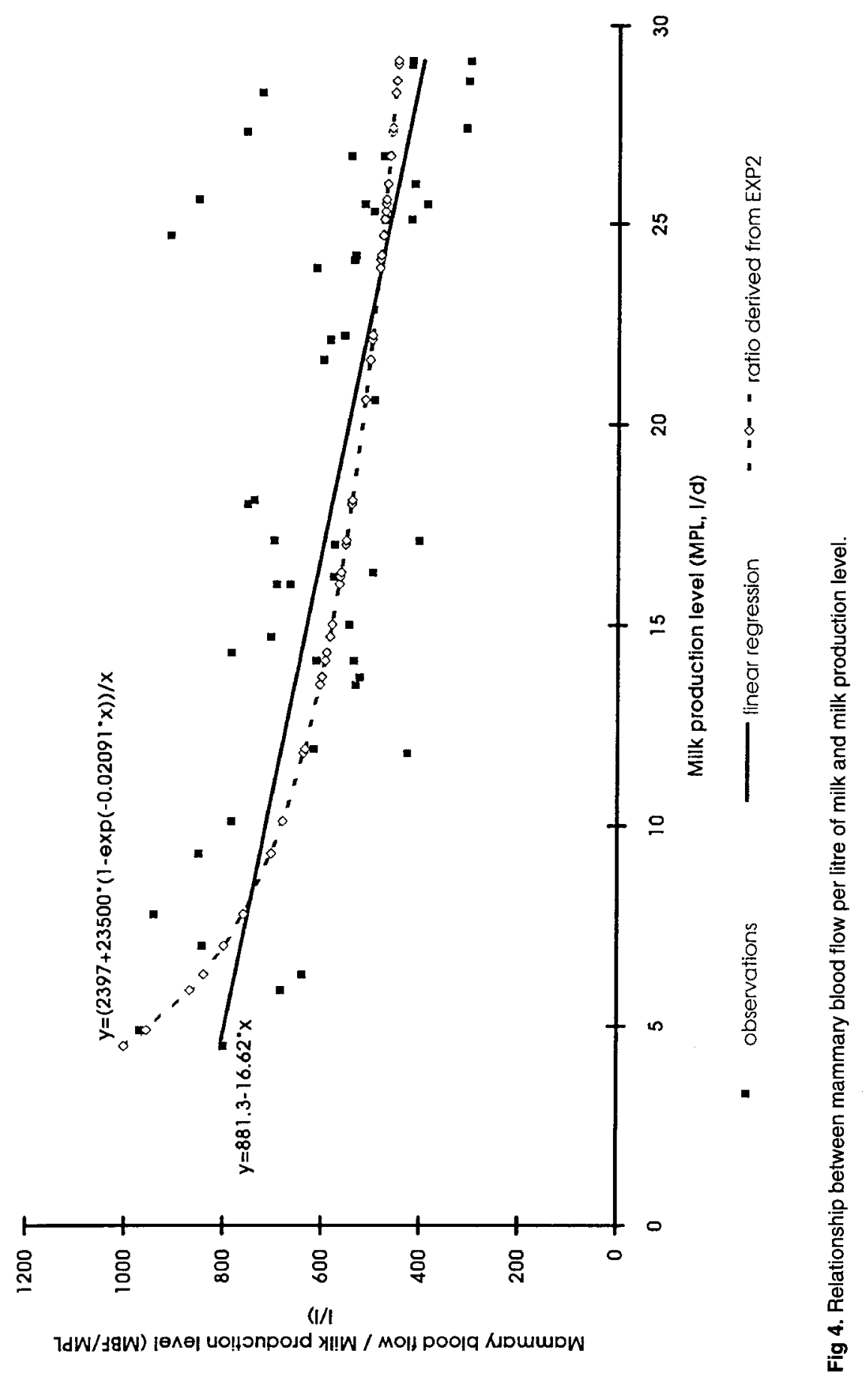


since MaBF/MPL tended to increase to infinity for this level of production:

$\mathrm{MaBF} / \mathrm{MPL}_{\mathrm{ij}}=881.3-16.62 \times \mathrm{MPL}_{\mathrm{i}}+\varepsilon_{\mathrm{ij}}$

$n=48, R^{2}=0.53, \mathrm{RSD}=107.3$

The average ratio was $578 \mathrm{~L}$ of blood flow per litre of milk produced, but the range was large: from 300 for high producing cows to 1000 for low producing cows. The same trend was found in goats by Linzell (1974). This decrease in the MaBF/MPL was observed throughout lactation. MaBF/MPL had an inverse shape compared to the usual production curve. These data do not a priori imply a lower flow of available nutrients for the synthesis of milk in high producing cows. It could be equally well be assumed that the nutrient uptake from the blood is more efficient or there are higher blood nutrient concentrations, or even that alternative sources of nutrients are available in the blood of high producing cows. However, this linear regression is only valid in the range 1.5-3.0 L/day. A more consistent curve could be derived from the division of EXP2 by MPL. This curve has been included in figure 5 . When no milk is produced, the blood/milk ratio is calculated as infinity and there is a minimal mammary blood flow per litre of milk produced for high producing dairy cows (eg, $372 \mathrm{~L}$ per litre of milk produced for $50 \mathrm{~L} /$ day cow).

The blood flow through the mammary gland varies greatly. More mechanistic knowledge is needed on the regulation of this flow since it transports metabolites to this organ. Cant (1995) proposed the first mechanistic model of MaBF, which included the effects of blood pressure and integrated the number of open capillaries in the mammary gland. From this first approach, further developments are needed to integrate the hormonal influence known to affect MaBF (Dhondt et al, 1973) and thus to predict the mammary blood flow.

\section{Comparison between different tissues}

The main purpose of this section is to compare blood flow values irrigating different

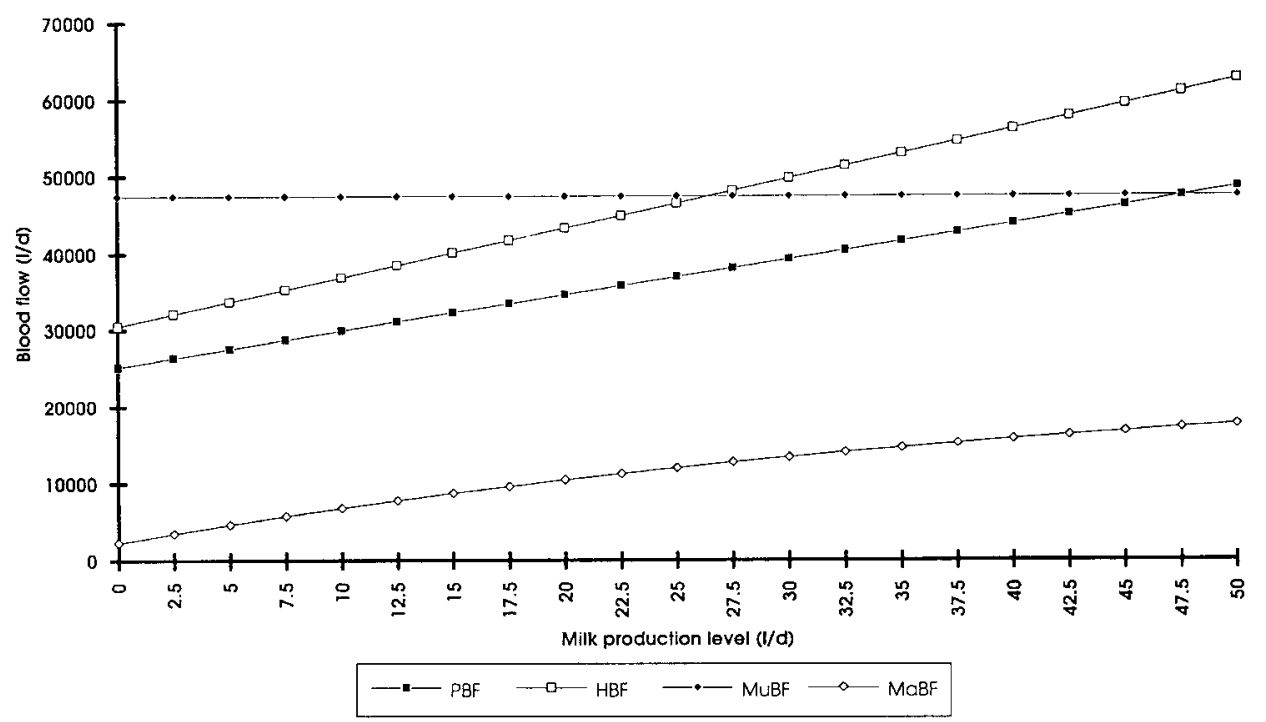

Fig 5. Simulation of blood flows between different organs and tissues as affected by milk yield. 
tissues. For this purpose, the above empirical relationships examining blood flow to each organ were used. A simple simulation was carried out for a $600 \mathrm{~kg}$ liveweight cow, producing $0-50 \mathrm{~L}$ of milk per day and eating $0.27 \times$ (milk production level) $+0.01 \times(B W-$ $600)+11 \mathrm{~kg}$ dry matter (INRA, 1988). It must be recalled that the MaBF data available were from cows producing $0-30 \mathrm{~L}$ of milk and that none of the AMuBF data comes from lactating cows. Therefore, the simulations are rough predictions which need to be used cautiously, especially for the muscle blood flow. Portal blood flow was adjusted with the ME intake equation from table II, with ME expressed in MJ/day. Hepatic blood flow was also adjusted with the equivalent ME intake equation, with $M E$ in $\mathrm{MJ} /$ day. The ME density was $11.5 \mathrm{MJ} / \mathrm{kg}$ dry matter intake. MaBF was simulated by the EXP2 equation from table V. AMuBF was taken to be related only to metabolic weight. The simulations (fig 5) showed large differences between organs with regards to daily blood flows, with the ranking being dependent on the milk production level. Except for the muscle, these flows are greatly increased with increasing milk production level. Data of cardiac output (Huntington et al, 1990) were compared with the liver output, the latter being assumed to represent one third of the cardiac output. The simulation of HBF was in agreement with this value.

This first section of this review discussed the variations in blood flows through the different key organs of protein metabolism and underlined the fact that a very large quantity of nutrients can be transported in the organism during lactation. This set of regressions, however, did not take into account possible physiological regulations, except for milk production level. Consequently, the distribution of blood in the whole body in homeorhetic situations, for example rapid growth or the beginning of lactation, could not be accurately predicted.

\section{AMINO ACID FLOWS}

\section{Amino acid absorption through the portal-drained viscera}

Ruminal amino acid metabolism has been extensively studied and, even if precise quantitative data are lacking, two feed unit systems for dairy cows (O'Connor et al, 1993; Rulquin et al, 1993) and a mechanistic model (Lescoat and Sauvant, 1995) can now predict the net amino acid supply to the duodenum. Methods were developed to assess the apparent absorption of proteins and amino acids in the small intestine with the mobile nylon bag technique (eg, Skórko-Sajko et al, 1994) and the results obtained seem to be relevant to the actual absorption (T Hvelplund, personal communication). In addition, the net amino acid appearance in the portal blood has been quantified via arterio-venous difference methods (eg, Huntington and Prior, 1985). These experiments, however, did not take into account amino acid metabolization in the portal drained viscera due to the use of non-labelled amino acids. Tagari and Bergman (1978) underlined large differences between the quantities apparently absorbed in the small intestine and those released in the portal blood. More precisely, amino acids such as alanine (Ala) could be synthesized in enterocytes by transamination of other amino acids or from other precursors. In the human intestinal wall, arginine (Arg) is metabolized with the appearance of urea, ornithine (Orn) and citrulline (Cit) (Jungas et al, 1992). The amino acid profile in portal blood is the result of the absorption profile, the arterial supply and the subsequent metabolism. Relatively little data have been published on the arterio-venous fractional release of amino acids in the portal-drained viscera.

A set of 27 observations of amino acids analysed in plasma were collected from ten 


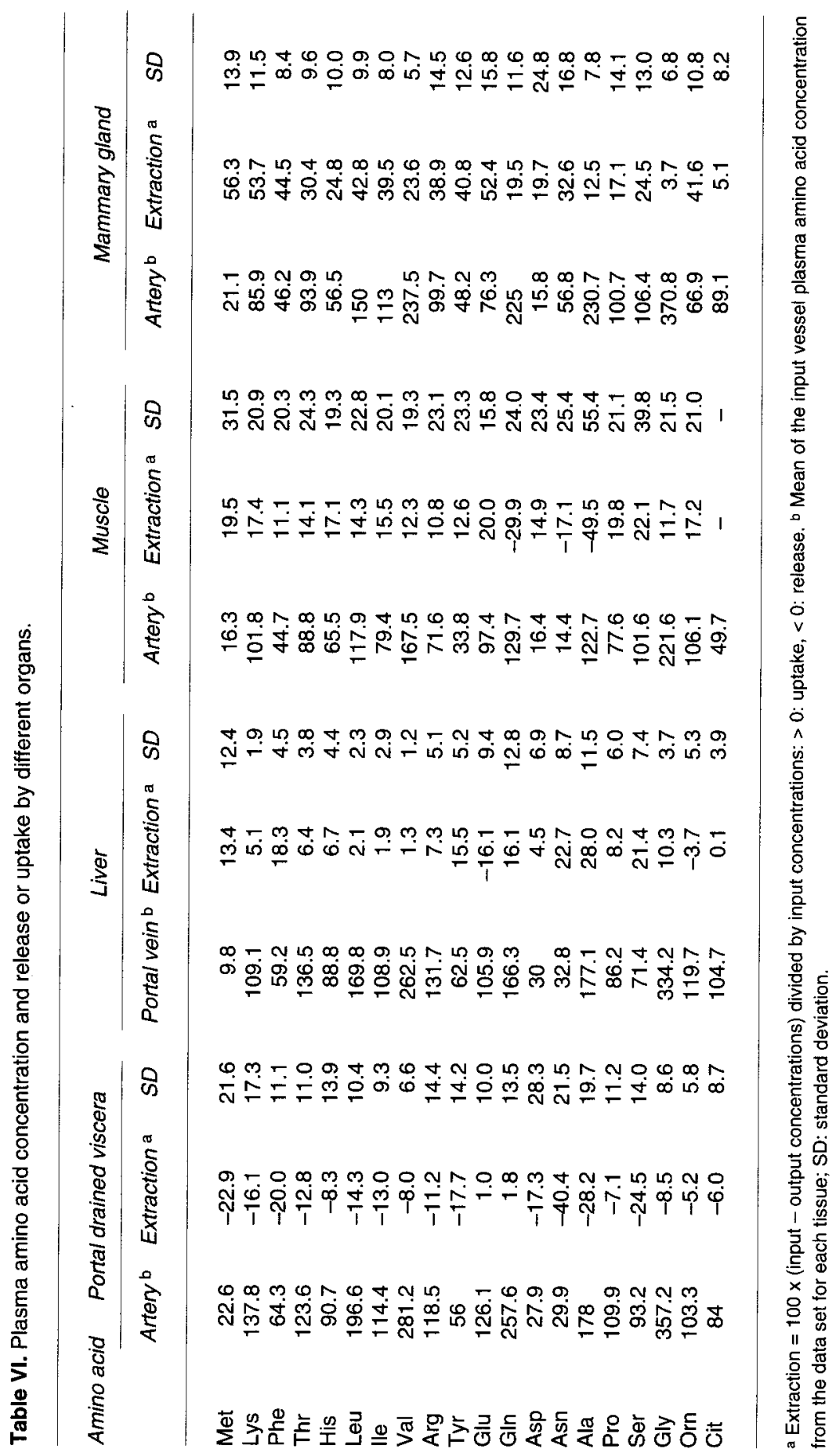


publications (Hume et al, 1972; Huntington and Prior, 1985; Prewitt et al, 1975; Prior et al, 1981; Reynolds et al, 1992, 1994b; Seal et al, 1992; Sniffen and Jacobson, 1975; Tagari and Bergman, 1978; Wolff et al, 1972). These data included the amino acids generally considered as essential (eg, O'Connor et al, 1993): methionine (Met), lysine (Lys), phenylalanine (Phe), threonine (Thr), histidine (His), leucine (Leu), isoleucine (lle), valine (Val) and Arg, as well as tyrosine (Tyr), Glutamate (Glu), Glutamine (Gln), aspartic acid (Asp), asparagine (Asn), Alanine (Ala), proline (Pro), serine (Ser), glycine (Gly), Orn and Cit, which are non-essential amino acids. Some data on amino acid analysis of whole blood were also available. Most of these latter values only concerned the following three gluconeogenic amino acids: Ala, Glu and GIn. Large variations in amino acid release, defined as portal vein minus arterial concentrations divided by arterial concentrations (\%) were observed. A statistical summary is presented in table VI.

These variations could be partly explained by analytical methods, especially the deproteinization of plasma or whole blood as observed by Ohara and Ariyoshi (1979) or Bernard and Rémond (1995) and described by Reynolds et al (1994a). The position of the catheter in the vein could also influence the arterio-venous differences, due to the varying number of gastro-intestinal organs included. Neutze et al (1994) found that the net blood appearances of Phe and Tyr were several times higher if the catheter was placed near a cranial mesenteric vein, which represents the small intestine irrigation, compared with the usual portal vein preparation, which drains the whole portal-drained viscera. This observed difference in net appearance could be explained by a dilution effect. Glu and GIn are taken up in higher amounts than they are released by the portal drained viscera. They are used as energy sources by the gut (Britton and Krehbiel, 1993). These variations did not appear as a significant statistical effect since the standard deviations were too high. Nevertheless, if data from animals fed ad libitum are compared to the net amino acid release in animals fed at maintenance, a trend appears revealing a

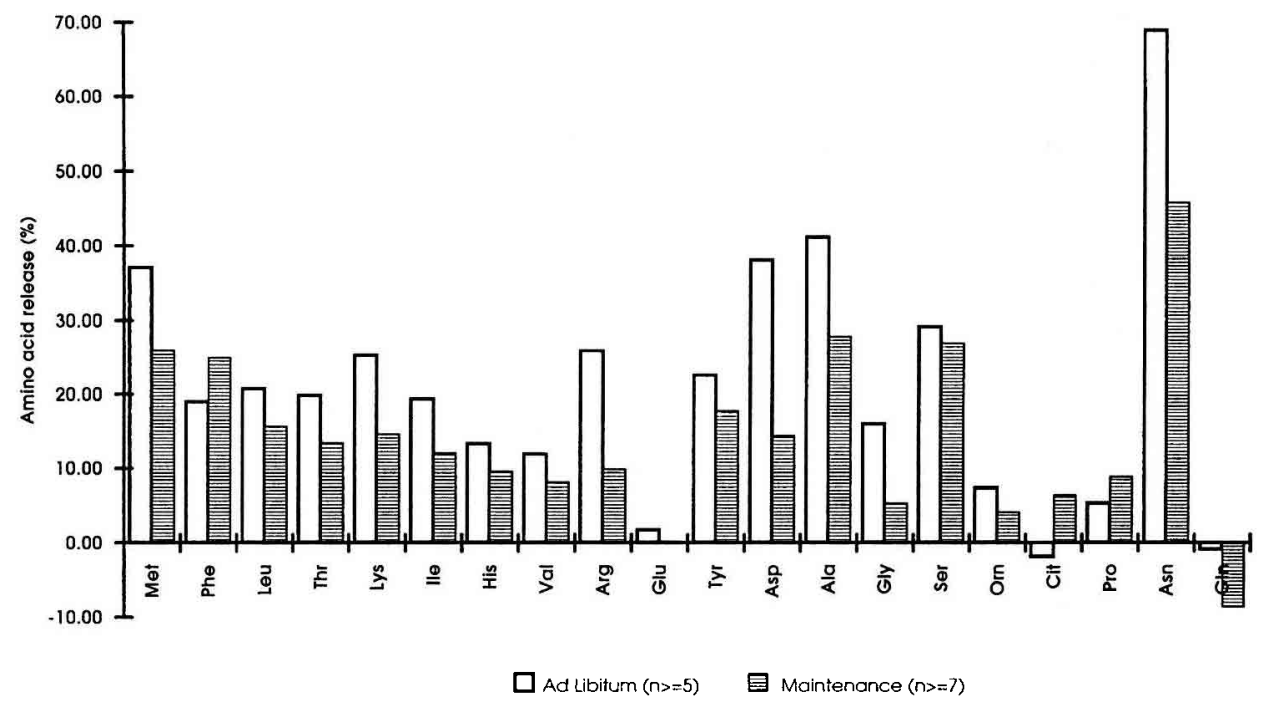

Fig 6. Amino acid release by portal drained viscera as influenced by nutrition level. 
higher release in the portal blood of the ad libitum fed animals (fig 6 ).

A set of 18 publications (Burrin et al, 1991; Casse et al, 1994; Gross et al, 1988; Guerino et al, 1991; Harmon et al, 1988; Huntington, 1984, 1987; Huntington and Prior, 1985; Huntington et al, 1983; Krehbiel et al, 1992; Lomax and Baird, 1983; Reynolds and Huntington, 1988; Reynolds and Tyrrell, 1991; Reynolds et al, 1988, 1991, 1992a, 1994b; Seal et al, 1992), including 71 observations, were collected to analyse the relationships between some general indicators of amino acid metabolism and level of intake and also between the portal-drained viscera and the liver. The information collected included the animal weight $(\mathrm{W}, \mathrm{kg}$ ), dry matter intake (DMI, $\mathrm{kg} /$ day), portal blood flow (PBF, L/day), portal-drained viscera and liver net release of ammonia $\left(\mathrm{NH}_{3}-\mathrm{N}, \mathrm{mmol} /\right.$ day), urea-N (Urea$\mathrm{N}, \mathrm{mmol} /$ day), and amino acid-N (AA-N, $\mathrm{mmol} /$ day), dry matter intake divided by metabolic weight (DM, g/day $\mathrm{kg}^{0.75}$ ) and AA-N appearance in the portal vein also divided by the metabolic weight (AA-NM $\mathrm{mmol} /$ day $/ \mathrm{kg}^{0.75}$ ). A statistical summary is presented table VII. There was a strong positive linear regression between dry matter intake and AA-N appearance on a metabolic weight basis (fig 7):

AA-NM $\left(\mathrm{mmol} / \mathrm{day} / \mathrm{kg}^{0.75}\right)=-14.0(5.5)$ $+0.769(0.065) \times D M\left(g /\right.$ day $\left./ \mathrm{kg}^{0.75}\right)$

$$
n=51, R^{2}=0.74, \mathrm{RSD}=13.55
$$

For animals fed less than 18.2 $\mathrm{g} /$ day $/ \mathrm{kg}^{0.75}$, the uptake by the portaldrained viscera was higher than the release in portal blood. This regression supported the trend for a higher release of most amino acids with an increase in feed intake (fig 6) and was in agreement with the results of Huntington et al (1988). This first step helped to obtain an overall view of the amino acid metabolism but it did not explain the variations in individual amino acids.

Data on individual amino acids were only obtained from plasma analyses. Consequently, the release as peptides or amino acids attached to red blood cells was not

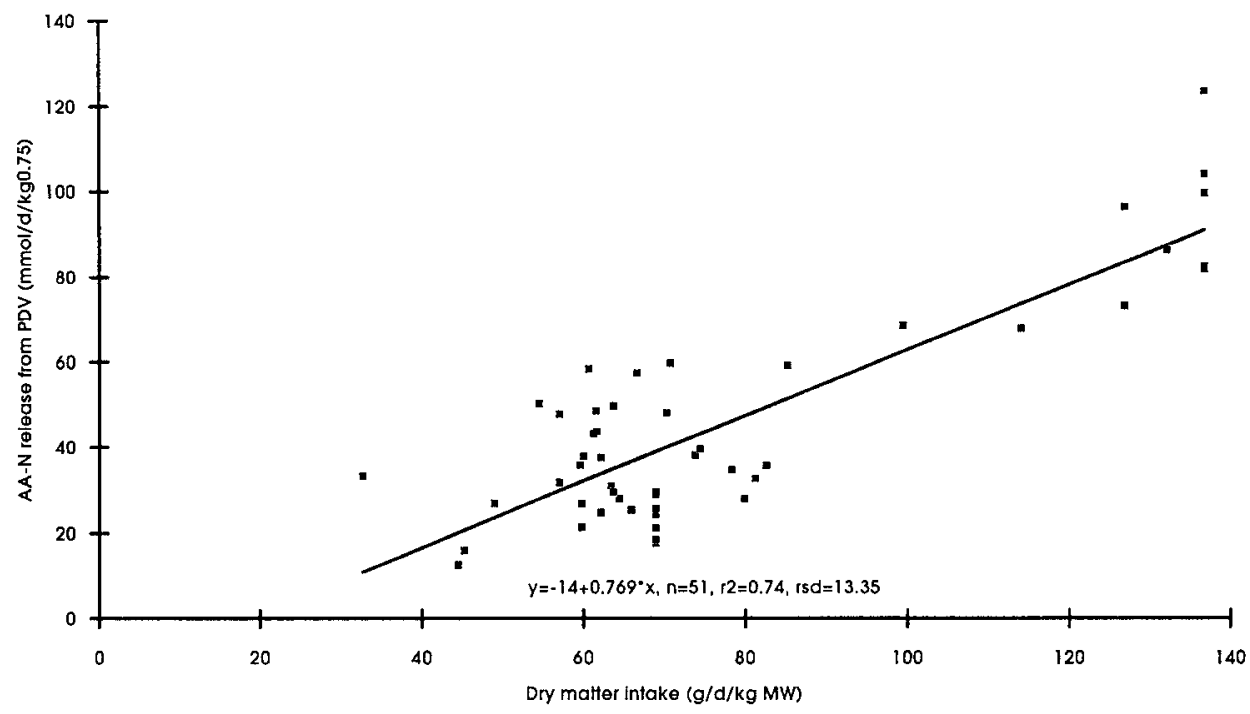

Fig 7. Relationship between portal drained visceral as release of amino acid- $\mathrm{N}$ and dry matter intake per $\mathrm{kg}$ metabolic live weight. 
considered, even though this has been proven to represent a large proportion of the amino acids released into the portal blood (Koeln et al, 1993) at least for several amino acids. There is a lively debate concerning whether amino acids are released and transported from the intestinal wall to the portal blood as peptides or as erythrocyte-free amino acids. Webb et al (1992) reported an extensive absorption of peptides from the intestinal lumen, but the mechanism for their release into the portal blood remains unclear (Reynolds et al, 1994a). This is aggravated by analytical problems in preserving only the peptides available for tissues in the analysed samples (Backwell, 1994). Additional work is needed on portal-drained viscera to determine the factors regulating amino acid metabolization and transport through the viscera and in the blood. Due to the high protein turnover rate in the portal drained viscera, the high blood flow draining these tissues and the lack of knowledge concerning blood amino acid transport, a reliable quantification will be technically diffcult to achieve.

\section{Amino acid metabolization by the liver}

Liver metabolism is highly active. It accounts for $25 \%$ of the whole body $\mathrm{O}_{2}$-uptake while the liver itself represents only $1.5 \%$ of total body mass in lactating cows (Huntington, 1990). This high energy activity is linked to a high rate of amino acid metabolism. The amino acids taken up by the liver are used in different metabolic pathways such as liver protein synthesis, gluconeogenesis and ketogenesis, synthesis of blood proteins, and amino acid transamination and oxidation. Consequently, the net amino acid release is unable to elucidate the liver amino acid utilization and few published values are available using labelled nutrients in vivo. This approach would, however, help to determine the fate of amino acids in the liver. For example, amino acid use for glucogenogenesis by the liver is highly variable depending on the availability of glucogenic nutrients and maybe also on the hormonal concentrations (Danfær et al, 1995). Nevertheless, the few data available on net amino acid release by the liver were used to study an 'apparent' amino acid liver metabolism.

A set of 15 observations were collected from four publications with the amino acid levels analysed in plasma (Brockman et al, 1975; Reynolds et al, 1992, 1994b; Wolff et al, 1972). The extraction ratios were corrected to take into account the contribution from the portal vein and the hepatic artery.

Table VII. Statistical summary of the data set on portal drained viscera and liver amino acid metabolism.

$\begin{array}{lcccc}\text { Variable (unit) } & \mathrm{n} & \text { Average } & \text { Standard deviation } & \text { Range } \\ & & & & \\ \text { Weight (kg) } & 62 & 376.9 & 114.4 & 33-651 \\ \text { Dry matter intake (kg/day) } & 60 & 6.64 & 4.78 & 0-21.8 \\ \text { Portal blood flow (L/day) } & 67 & 18144 & 9334 & 2088-51384 \\ \text { PDV ammonia release (mmol/day) } & 62 & 4847 & 3395 & 504-13872 \\ \text { PDV urea-N uptake (mmol/day) } & 64 & 3296 & 2685 & 12384-320 \\ \text { PDV Aa-N release (mmol/day) } & 62 & 3505 & 2999 & -1958-13008 \\ \text { Liver ammonia uptake (mmol/day) } & 28 & 4717 & 3299 & 14184-552 \\ \text { Liver urea-N release (mmol/day) } & 30 & 8702 & 6468 & 1512-24192 \\ \text { Liver Aa-N uptake (mmol/day) } & 33 & 1772 & 1218 & 5232-144\end{array}$


A statistical summary of the values is presented in table VIII.

The feed intake level did not seem to increase the hepatic uptake of essential amino acids (fig 8 ). There was nearly no uptake or release of branched-chain amino acids irrespective of the level of intake. This is in agreement with Harper et al (1984) who reported the liver's low capacity to take up and degrade branched-chain amino acids. For non-essential amino acids (fig 8), apparent differences existed between nutritional levels, but the extent of increase or decrease differed between the individual amino acids. Gluconeogenic amino acids were extensively taken up and stored by the liver, except Glu, which was also used for transamination of other amino acids. There was a trend towards an increase in Orn release in animals fed at maintenance. This could be related to the urea cycle. However, too few data were available (nine for each amino acid except for His (3)) and their variations were too large to obtain any significant statistical effect.
As a preliminary conclusion, it can be stated that the liver had a major role in the amino acid removal rate. Moreover, it influenced the blood amino acid profile and consequently amino acid availability for milk or muscle protein production.

The portal-drained visceral tissues and the liver are two highly active compartments with regards to amino acid metabolism and anatomically they are in a series. They should therefore be studied together. They alter the quantity and the composition of the available amino acid pool between what escapes the rumen and what is delivered into the hepatic vein for growth and maintenance of tissues and for milk protein synthesis. Amino acid release by portal-drained viscera or removal by the liver, expressed in $\mathrm{mmol}$ of amino acid- $\mathrm{N}$ per day, is usually used to monitor amino acid metabolism in the splanchnic area.

From the data set summarized in table VII, a linear regression was found between the AA-N release in the portal blood and the net use by the liver on a metabolic weight basis (fig 9a).

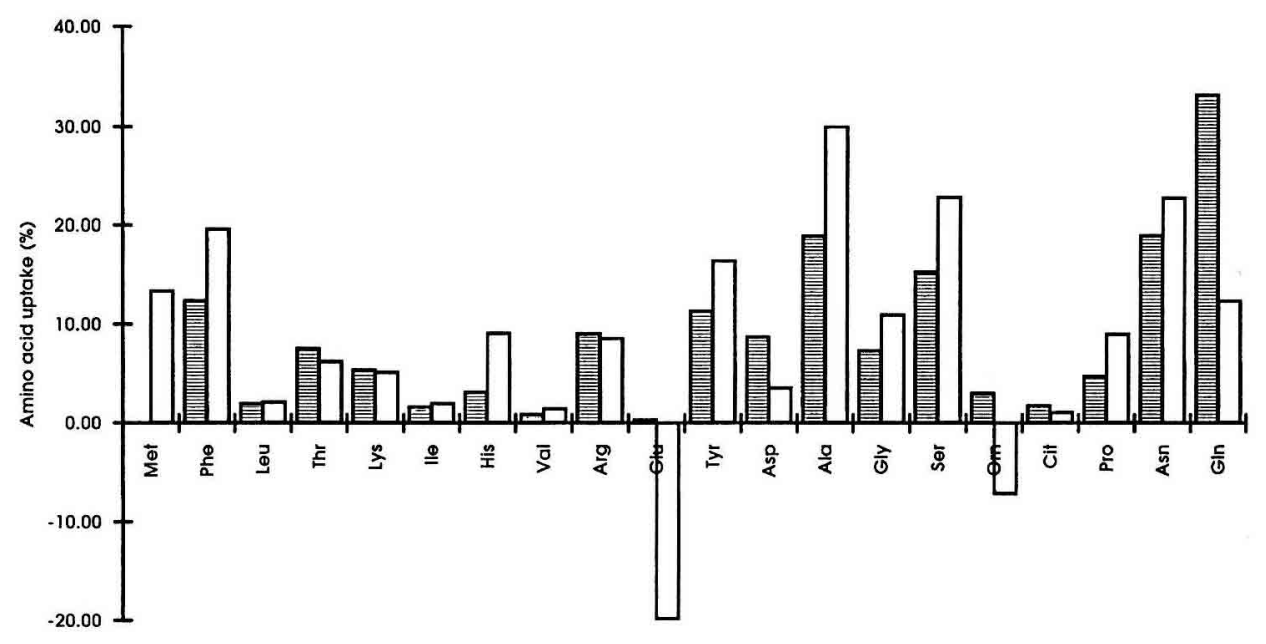

目 Ad Libitum (ns=2, except Met ond Asn $(n=0)) \square$ Maintenonce $(n=9$, except His $(n=3))$

Fig 8. Hepatic uptake of individual amino acids as affected by level of nutrition. 
AA-N(liver, $\mathrm{mmol} /$ day $\left./ \mathrm{kg}^{0.75}\right)=$ $-13.1(4.25)+1.065(0.117)$

x AA-N(PDV, $\left.\mathrm{mmol} / \mathrm{day} / \mathrm{kg}^{0.75}\right)$

$n=24, R^{2}=0.79, \mathrm{RSD}=7.76$

From this equation and the data set, an average of $65 \%$ of the amino acids released in the portal blood were apparently used by the liver. This seems high in relation to the amino acid requirements for production and maintenance. The regression is only valid for a daily portal-drained visceral AA-N release lower than $5500 \mathrm{mM} /$ day (about $68 \mathrm{mmol} / \mathrm{day} / \mathrm{kg}^{0.75}$ ). AA-N is only an over-
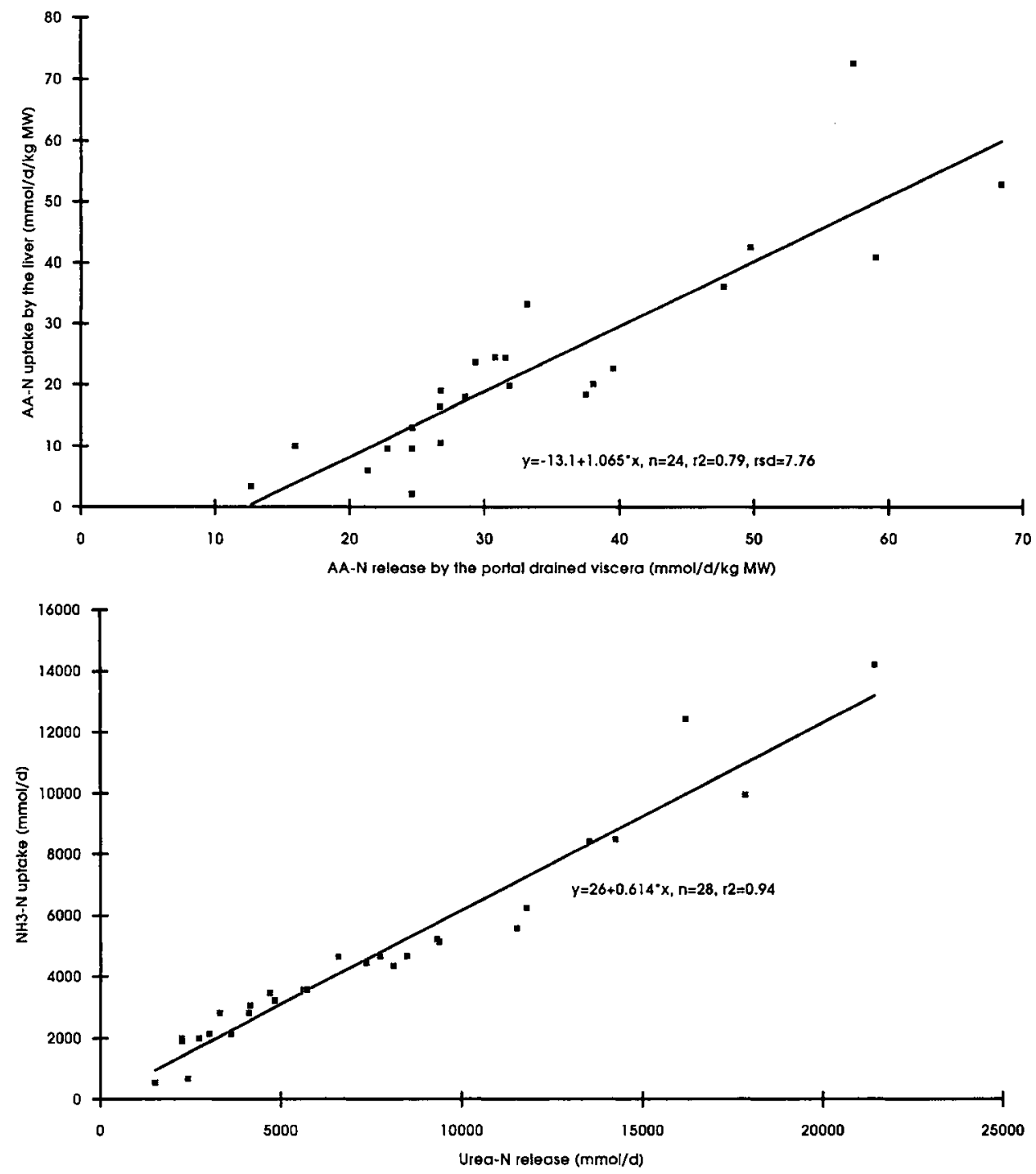

Fig 9. A. Relationship between $A A-N$ release by portal drained viscera and $A A-N$ uptake by the liver. B. Relationship between $\mathrm{NH}_{3}-\mathrm{N}$ uptake and urea-N release by the liver. 
all view of whole amino acid metabolism. Since the different amino acids are not taken up at the same rate by the liver (fig 8), AA-N may not represent the quantitative variations and availability of individual amino acids. $A$ study of each amino acid appears necessary to understand the actual availability of these nutrients for systemic utilization.

To support this point, an example of the utilization of amino acids in the liver was given indirectly by the following regression between urea- $\mathrm{N}$ release by the liver and its $\mathrm{NH}_{3}-\mathrm{N}$ uptake (fig $9 \mathrm{~b}$ ):

$\mathrm{NH}_{3}-\mathrm{N}$ (liver, mmol/day) $=26(268)$ $+0.614(0.029) \times$ Urea-N (liver,mmol/day) $n=28, R^{2}=0.94, \mathrm{RSD}=790$

This regression revealed that $39 \%$ of the nitrogen used in ureogenesis came from sources other than $\mathrm{NH}_{3}-\mathrm{N}$, notably deamination of amino acids. This was consistent with the results of Lobley et al (1995), who demonstrated that $\mathrm{NH}_{3}$ extracted by the ovine liver could provide $61-70 \%$ of the $\mathrm{N}$ found in urea. In conclusion, further studies should be undertaken with the aim of establishing the fate of individual amino acids in the liver.

\section{Amino acid utilization muscles}

Muscle tissues modify the amino acid profile (Teleni, 1993). It therefore appears necessary to study the net amino acid release by muscle tissues in order to predict the quantity available for other organs. A set of 49 observations were collected from 12 publications with data concerning amino acids analysed in plasma (Ahmed et al, 1983; Bell et al, 1975; Brown et al, 1991; Huntington and Prior, 1985), in whole blood (Ballard et al, 1976. Boisclair et al, 1993a, 1994; Early et al, 1987; Teleni et al, 1986), in erythrocytes and in plasma peptides (Danilson et al, 1987a,b; McCormick and Webb, 1982). The information collected was the animal species, experimental factor tested, arterial amino acid concentrations $(\mu \mathrm{M})$, uptake of amino acids by muscle (arterial minus venous divided by arterial concentration, \%). A statistical summary of the amino acid release analysed in plasma is presented in table VI.

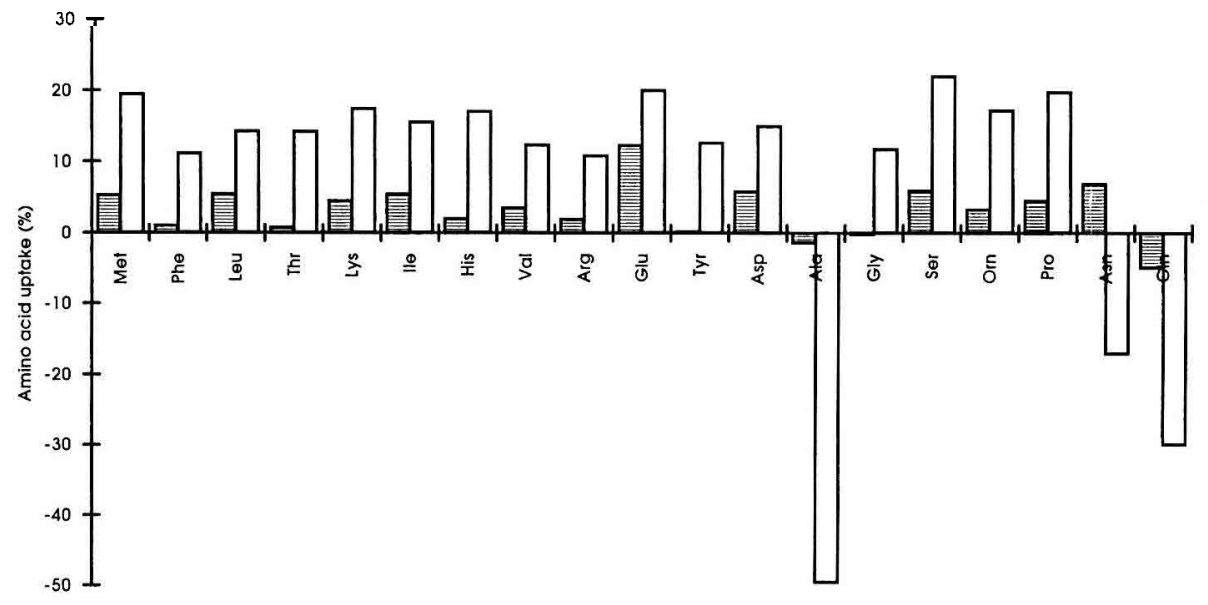

을 Whole blood analysis $3<=\pi \mid<=14 \square$ Plasma analysis $18<=1<=26$

Fig 10. Uptake by muscle tissues of individual amino acids from whole blood or from plasma. 
Most of the observations in this section were from growing steers. Hence, these data cannot be regarded as a good representation of the amino acid metabolism in the muscle tissues of lactating ruminants, especially in early lactation when the mobilization of amino acids from the muscles can be substantial (Andrew et al, 1994). Another problem is that about half of the data were obtained on whole blood, as the amino acid release based on whole blood appears to differ from the release based on plasma for most amino acids (fig 10). The same pattern was observed for the amino acid uptakes, but the uptake values were multiplied by a common 'scaling-up factor' between plasma and whole blood. The choice between one or the other of these data sets is difficult. The high plasma values conflict with the small gain or loss in the muscle protein compartment that can be registered on a daily basis. To balance these high uptakes, other amino acid carriers have to be considered in the muscles viz amino acids attached to the erythrocytes and the blood peptides. These two amino acid compartments were quantitatively compared with plasma free amino acid uptake. Amino acids were released into the free amino acid compartment in the erythrocytes and were taken from the plasma peptide compartment for most of the essential amino acids. This conflicts with the assumption of a balance between amino acid uptake and release for the latter compartment. For nonessential amino acids the conclusions are unclear (Danilson et al, 1987a, 1987b). More investigations are needed to evaluate the quantitative importance of amino acids in relationship to the erythrocytes and blood peptide amino acids and also to clarify the choice between whole blood or plasma analysis for uptake and release studies of individual amino acids by muscle (Armentano, 1994). An additional problem may arise from the variations in the packed cell volume between tissues and between experiments.
The observed standard deviations were high for the analysis of amino acid release into plasma. There was a net uptake of all the amino acids except for Asn, GIn and especially Ala, which were released into venous blood. This net GIn production served as a vehicle for removing excess $\mathrm{NH}_{4}^{+}$from the muscles and as a gluconeogenic precursor, while Ala flowed to the liver as a part of the Ala-glucose substrate cycle previously demonstrated in man (Christensen, 1990). Several factors influenced the ratio of amino acid uptake. For essential amino acids, this uptake ratio increased with level of nutrition, with the dietary protein content and with injection of exogenous insulin. These results, observed by Ahmed et al (1983), were confirmed by other experiments (Boisclair et al, 1993a). Explanations of the decreased uptake of amino acids by the muscles with underfeeding or fasting could be due to changes in the oxidation levels of some amino acids, their transformation into ketoacids or a decrease in net retention. The same trend was observed with non-essential amino acids. Muscle, like the liver, appeared to partially participate as a 'short term buffer' for the amino acid supply and thus helped to maintain homeostasis in the organism, even though the amino acid metabolism was significant in this tissue. This implied that the pattern of amino acid release differed largely from that of uptake, as observed in rats (Chang and Goldberg, 1978). All these modifications might be connected to energy metabolism in the ruminant with a net production of gluconeogenic amino acids via the utilization of others.

To understand the net release of amino acids by muscle, the metabolic pathways between different nutrients have to be taken into account simultaneously. Their regulation also has to be considered. Unfortunately, as for muscle blood flow, little is quantitatively known about the in vivo regulation of these biochemical pathways. As for the study of splanchnic bed amino 
acid metabolism (Biolo et al, 1992), multiple infusions of labelled nutrients, including sources of energy, could be performed to understand more about some of the interactions between amino acids and other nutrients.

\section{Amino acid uptake by the mammary gland}

Blood amino acid extraction by the mammary gland has been extensively studied in lactating cows. According to Fick's principle, the extraction ratio ((artery-venous)/ artery concentrations) is one of the three components necessary to determine the absolute quantity of amino acids taken up by the mammary gland. The other two components are the mammary blood flow and the amino acid concentration in the artery. Consequently, increased amino acid concentrations or blood flow would increase the mammary uptake if the extraction ratio were constant or if it varied independently of the two first factors. This is called the 'push' hypothesis, which postulates that the amino acid availability for milk protein synthesis is regulated by blood irrigation and amino acid concentration. If, on the other hand, the extraction ratio decreased with an increase in blood flow or amino acid concentration, then the quantities taken up would be determined by mammary gland metabolism; this is the 'pull' hypothesis, supported by the review of Knight et al (1994). Nevertheless, the regulation of the amino acid uptake ratio remains unclear (Hanigan et al, 1992). Usually, the analysis of amino acids in the plasma is used to monitor the mammary gland amino acid uptake even though it does not seem sufficiently accurate (Guinard and Rulquin, 1994). Red blood cells (Hanigan et al, 1991) and peptides (Backwell, 1994; Bequette et al, 1994) also deliver amino acids to the mammary gland for milk protein synthesis and mammary gland tissue maintenance and growth.

The influence of the supplied amino acid profile and the hormonal state have been studied by several authors. A set of 86 observations from 26 publications on plasma free amino acid extractions in lactating cows were collected (Ahrar and Schingoethe, 1979; Austin et al, 1991; Bickerstaffe et al, 1974; Block et al, 1981; Cant et al, 1993; Casper and Schingoethe, 1988; Casper et al, 1987, 1990; Clark et al, 1974; Clark, 1975; Derrig et al, 1974; Drackley and Schingoethe, 1986; Erickson et al, 1992; Guinard and Rulquin, 1994; Hadsell and Sommerfeldt, 1988; Huber et al, 1984; Illg et al, 1987; Kellaway et al, 1974; King et al, 1990; Klusmeyer et al, 1987; Laarveld et al, 1981; Lanham et al, 1992; Munneke et al, 1991; Peeters et al, 1979; Seymour et al, 1990; Yang et al, 1986). The information collected was the raw milk production level (MPL, L/day), milk protein content (PC, $g / L)$, number of weeks post partum (SL, week), extraction ratio $(\%)$, and the amino acid concentration in the mammary artery. Table VIII is

Table VIII. Statistical summary of the data set on mammary amino acid extraction.

\begin{tabular}{lcccc}
\hline Variable (unit) & $\mathrm{n}$ & Average & Standard deviation & Range \\
\hline & & & & 7.3 \\
Milk production (L/day) & 70 & 24.8 & 3.0 & $11.5-39.3$ \\
Protein content (g/L) & 59 & 31.6 & 8.1 & $25.5-38.0$ \\
Weeks post-partum (week) & 46 & 13.5 & $7-37$
\end{tabular}


a statistical summary of the data set, except for the extraction ratio and artery concentrations which are given in table VI. Most of the amino acid extraction ratios varied greatly and the absolute values were high for the essential amino acids, which might indicate a critical requirement for these amino acids in the mammary gland.

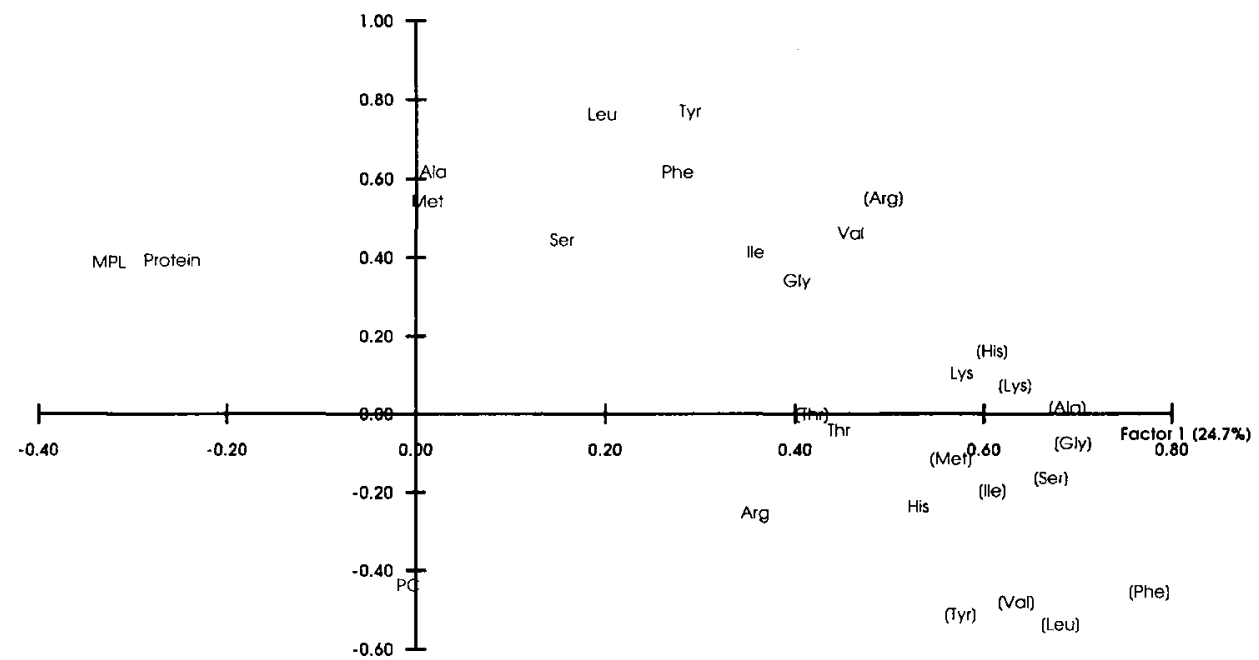

Factor $2(18.8 \%)$

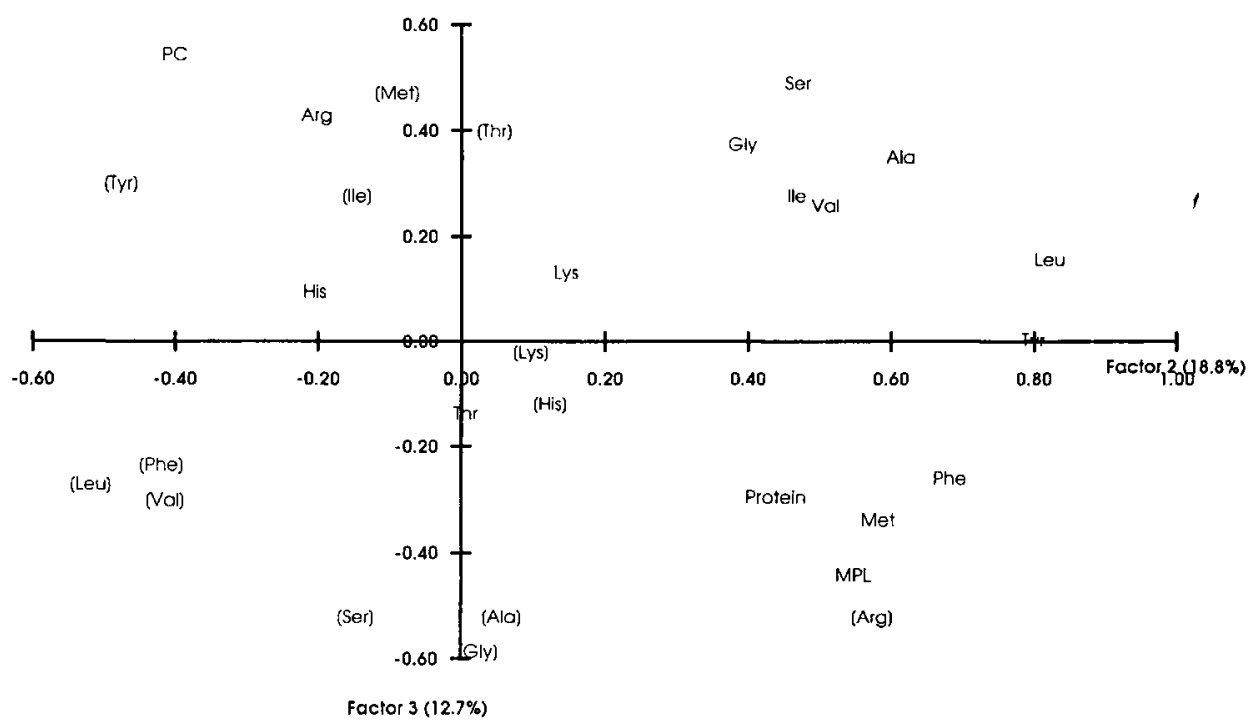

Fig 11. A. Correlation circle of the principal component analysis on the mammary gland amino acid uptake. MPL: milk production level, Protein: milk protein production, PC: milk protein content, Aa: uptake ratio, [Aa]: arterial amino acid concentration. Axes 1 and 2. B. Correlation circle of the principal component analysis on the mammary gland amino acid uptake. MPL: milk production level, Protein: milk protein production, PC: milk protein content, Aa: uptake ratio, [Aa]: arterial amino acid concentration. Axes 2 and 3 . 
Factors explaining the variations were not obvious and a principal component analysis (Saporta, 1990) was performed to obtain a global but simplified picture of the links between the different parameters in a 'restricted space'. The first three axes explained $56 \%$ of the variance, which was fairly satisfying when the data dispersion is considered. A plot of the first and second axes (fig 11a) showed positive correlations between most of the amino acid extraction ratios (except for Arg) and milk or protein production, and negative correlations with milk protein content on the second axis. However, the extraction ratio and MPL or protein production were negatively linked on the first axis except for Met and Ala. Consequently, extraction ratios and milk or protein production were nearly independent except for Met, Arg and Ala. The amino acid concentrations were poorly correlated with the amino acid extraction ratios on the first axis and negatively on the second, except for Lys, His and Thr. These observations were confirmed by a plot of the second and third axes except for Phe which gave results close to MPL and protein production (fig 11b). The concentrations and extraction ratios were negatively correlated on the third axis. Consequently, no significant regression was found between the extraction and the concentration of the amino acid, which agreed with the results of Cant (1995). From the principal component analysis observation, linear relationships were underlined between amino acid extraction and MPL, $\mathrm{PC}$ and milk protein production (PP), even if the $R^{2}$ values were low (table IX). MPL and $P C$ changed throughout lactation and quadratic relations were therefore found between Phe extraction ratios and the number of weeks post partum SL.

Met and Phe extraction ratios were the only extraction ratios linearly and significantly increased by MPL. A quadratic model for Met increased the $R^{2}$, but this was mainly obtained when two low milk production levels were used, where the extraction values were much higher than expected. The exclusion of these two 'influencing points' (Tomassone et al, 1992) demonstrated that a linear model was as relevant as a quadratic one. Another model has been proposed with an upper limit for the extraction ratio for high producing dairy cows. However, this approach did not improve the adjustment in the range of values included in the data sets and observations of amino acid extraction rates based on whole blood were excluded, which was not the case previously (Lescoat and Sauvant, 1994). Nevertheless, models with an extraction dependent on the level of milk production and with lower and upper limits might be more physiological,

Table IX. Regressions between the amino acid extraction ratio and the production variables.

\begin{tabular}{llrrr} 
Amino acid & $\mathrm{n}$ & Model $\mathrm{a}$ & $R S D$ & $\mathrm{R}^{2}$ \\
\hline & & & & \\
Met & 58 & $29.6(6.1)+0.993(0.224) \times \mathrm{MPL}$ & 11.3 & 0.26 \\
Met & 58 & $82.3(20.9)-25(1.63) \times \mathrm{MPL}-0.08(0.03) \times \mathrm{MPL} 2$ & 10.7 & 0.34 \\
Met & 51 & $-58.9(64)+6.65(2.3) \times \mathrm{MPL}+3.27(2) \times \mathrm{PC}-0.201(0.07) \times \mathrm{PP}$ & 10.5 & 0.41 \\
Phe & 58 & $32.8(4.3)+0.43(0.156) \times \mathrm{MPL}$ & 7.9 & 0.12 \\
Phe & 46 & $64.5(4.5)-2.03(0.54) \times \mathrm{SL}+0.038(0.012) \times \mathrm{SL}^{2}$ & 5.8 & 0.34 \\
Arg & 51 & $66.8(8.2)-0.0337(0.01) \times \mathrm{PP}$ & 12.3 & 0.19
\end{tabular}

\footnotetext{
a MPL: milk production level (L/day), PC: milk protein content ( $\mathrm{g} / \mathrm{L}), \mathrm{PP}$ : protein production (g/day), SL: stage of lactation (weeks). The standard errors of the parameters are given in brackets.
} 
even if our data did not allow discrimination in favour of such a model. A similar upper limit for the amino acid extraction ratio has been observed in goats with artificial hyperaminoacidemia, which induced a decrease in these ratios (Tesseraud et al, 1992). It could be assumed that a saturation of the transport process was reached or that mammary metabolism was driving amino acid extraction according to the 'pull' hypothesis.

The other significant factor was SL. The available data were generally obtained around peak lactation (8-12 weeks post partum) with none before and only a few at the end of lactation. Therefore, the regression slopes were influenced by a low number of end-lactation data. In fact, amino acid uptake seemed to reach a peak around eight weeks post partum and decreased slowly in the following months. These curves support the hypothesis of maximum efficiency for amino acid extraction in the case of high milk production levels. The Arg extraction ratio decreased linearly with daily milk protein production. The quantity extracted was much higher than the quantity exported as milk protein. It has been demonstrated that Arg is extensively metabolized in mammary cells which provide non-essential amino acids for milk protein synthesis (Clark et al, 1975). This decrease in the extraction ratio could be a limiting factor for milk protein production even if the mammary blood flow was simultaneously increased. Mammary artery concentrations of Arg are positively correlated with the level of milk production (figs 11a,b).

Extraction ratios could also be seen as the slope of regression between amino acid arterial concentration and arterio-venous differences. If a linear model is accepted and the intercept is around zero, then the extraction ratio could be considered as constant. $A$ good example of this was seen with Lys, with a slope of $53.7 \%$ and an intercept which was quasi nul. A more problematic amino acid was Met, with a high intercept and a low slope (39.3\%). A bias came from the fact that in this data set, high arterial concentrations were linked with low milk production. As a consequence, arterio- venous differences were lower than expected for high concentrations of Met and higher for low concentrations. The results for these two amino acids illustrate the wide differences in behaviour of nutrients in the mammary gland.

Correlations between essential amino acid extraction ratios appeared in the first plan of the principal component analysis (fig 11a). This was less obvious in the second plan (fig 11b). Most of the ratios were positively correlated. Close relationships were obtained between the branched-chain amino acids. This illustrated the assumption of modulated specific transport systems under the influence of physiological state. Phe and Arg were negatively linked. This negative correlation was also observed between $\mathrm{Thr}$ and lle. Amino acid transporters in the mammary cells are the same for several amino acids. Therefore, competitive inhibition or enhancement could explain some of the observed relationships between the amino acid extraction ratios (Baumrucker, 1985; Knight et al, 1994).

According to Cant et al (1993), sources other than plasma free essential amino acids are necessary to produce all the protein found in milk. Pocius et al (1981) demonstrated that a tripeptide, glutathione, was extracted from mammary blood. Bequette et al (1994) proposed that peptide uptake could fill the gap in essential amino acids for milk protein synthesis by lactating goats. They also proposed another hypothesis: that in the mammary cell, there may be protein storage which is progressively incorporated into milk protein. However, storage would only facilitate the uniformity of amino acid availability and would not fill a gap in supply. In conclusion, amino acids were taken up by the mammary gland to varying extents. For each amino acid, large varia- 
tions in uptake were observed and these remain poorly explained.

\section{Comparison between the amino acid fluxes in the different tissues}

Plasma free amino acid profiles and quantities were largely modified by their flows through the different protein compartments. Extraction or release ratios varied greatly. Some qualitative factors have been identified, namely that the level of intake increased the release by portal-drained viscera and the uptake by muscles of growing animals. Experimental design and analytical procedures should also be considered as qualitative influencing factors: deproteinizing agents and sample storage or analytical procedures added to the uncertainty in the amino acid concentrations and consequently their extractions. Milk production influenced some amino acid extraction ratios. However, none of these variations were strongly related to quantitative factors. Assumptions about the homeorhetic regulation of amino acid partition can be used to explain high extraction levels in the mammary gland during lactation and in the hindlimb of growing animals. This explanation is, however, totally theoretical and the modelling of a regulating sub-system relating amino acid utilization with homeorhetic and homeostatic control is difficult to calibrate (Sauvant, 1994).

This section was based only on results from plasma amino acid analysis. It must be kept in mind, however, that blood peptides and red blood cell amino acids are also to some extent available for tissue and organ amino acid requirements (Backwell, 1994). It would be interesting to reconsider the amino acid transport between organs and tissues taking into account these two compartments. This could contribute to a further elucidation

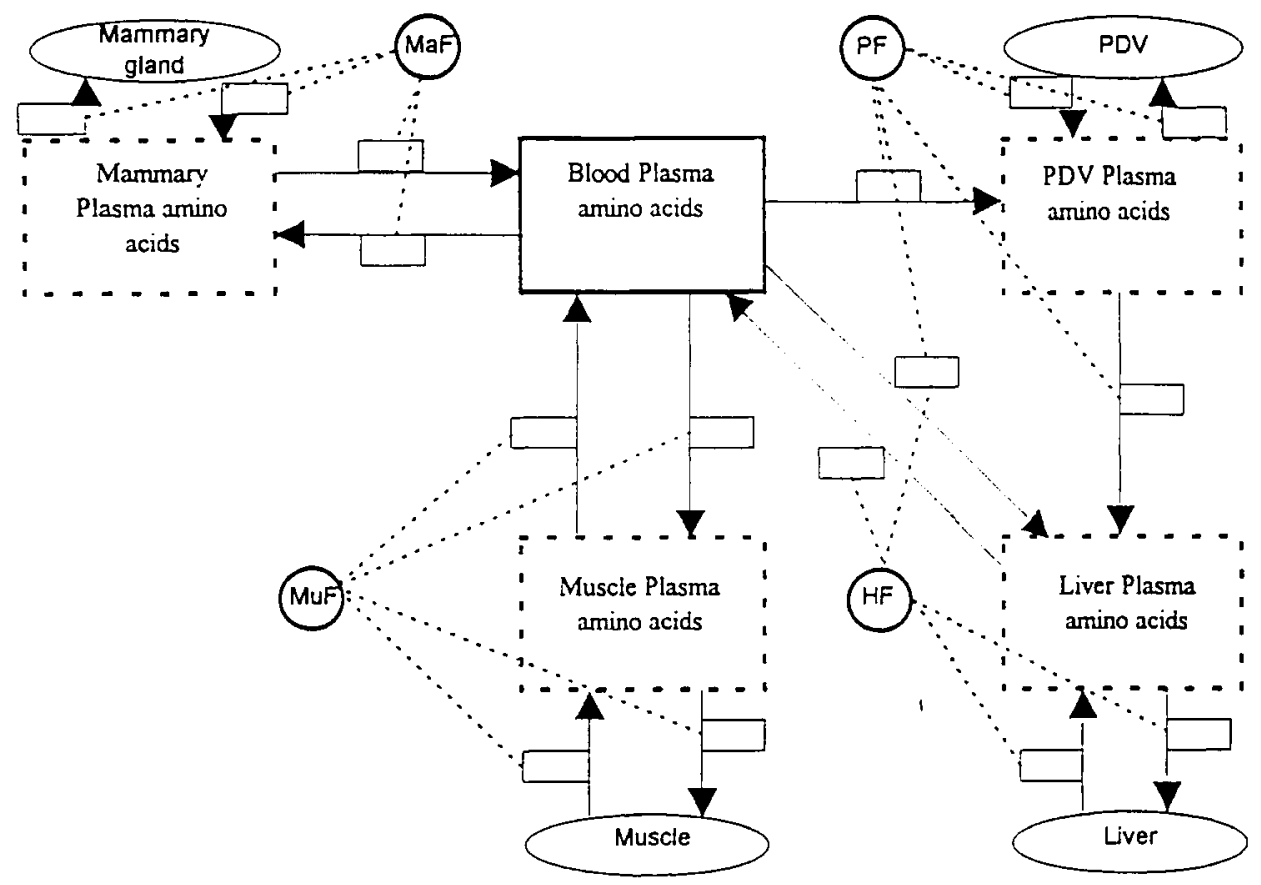

Fig 12. Diagram for a simulation model of amino acid fluxes in the organism. 
of the rules governing the amino acid partitioning between different tissues.

\section{SIMULATIONS}

Each of the above sections was a quantitative approach examining one factor related to amino acid metabolism: first of all, blood flows, which carry the amino acids between the organs and inside tissues, and secondly, net amino acid release or uptake by different compartments. A one-factor study was performed in each section. However, a summary of whole body amino acid fluxes with an integrated approach was required. Consequently, a static and empirical model of amino acid fluxes in the whole body of large ruminants was developed. Its aim was to calculate the adequacy of the amino acid supply in relation to the amino acid requirements from the equations obtained in the two previous sections.

Five amino acid blood compartments were considered: the mammary gland (1), portal drained viscera (2), liver (3), muscle (4) and the whole circulating blood (5). The blood was distributed between the com- partments according to the blood flow equations from the first section. By multiplying these fluxes by the amino acid concentrations in the arterial and portal blood and their uptakes or releases reported in table VI, the balance between supply and demand could be calculated. By using $24 \mathrm{~h}$ blood flow, the results were obtained on a daily basis. A diagram of the proposed model is presented in figure 12.

Two different animals were simulated: a lactating cow and a growing animal. The cow weighed $600 \mathrm{~kg}$ and produced $0-50 \mathrm{~L}$ of milk per day with a zero $\mathrm{N}$ balance in the muscle tissues. This simplification was necessary since no specific data on muscle amino acid extraction are available and we preferred to avoid speculative values for this flux. The results were expressed as a comparison between supplies and requirements and are presented in table $X$. These simulations helped to qualitatively rank the essential amino acids, bearing in mind all the drawbacks and limitations of this approach. They demonstrated that if only the free amino acids are taken into account, all the essential amino acids became limiting for milk protein production. There seemed to be two lines of explanation for these results.

Table X. Simulations of amino acid fluxes in the lactating cow.

Amino acid MIIk production level ( $L$ day)

$\begin{array}{llllll}0 & 10 & 20 & 30 & 40 & 50\end{array}$

\begin{tabular}{llllllll}
\hline Met & + & - & - & - & - & - & 4 \\
Lys & + & - & - & - & - & - & 4 \\
Phe & - & - & - & - & - & - & 1 \\
Leu & + & + & - & - & - & - & 7 \\
Ile & + & + & - & - & - & - & 7 \\
Val & + & + & - & - & - & - & 7 \\
Thr & + & - & - & - & - & - & 4 \\
His & - & - & - & - & - & - & 1 \\
Arg & - & - & - & - & - & - & 1
\end{tabular}

+ : the supply is higher than the requirements, - : the supply is lower than the requirements. 
First of all, these simulations did not take into account the parameter variations related to factors like the physiological stage of the animal, or the correlations between parameters. Thus, a regulating subsystem should be included to drive the parameter values of this simple model. This could not be done in the present effort as no significant factors were found that influenced the model parameters. Secondly, the shortage of amino acids illustrated the possibility of the existence of other sources of amino acids such as small peptides, amino acids bound to erythrocytes and small proteins exported from the liver.

The second group of simulations represented the amino acid fluxes in growing cattle. Only amino acid exchanges between the muscle and the whole blood compartment were simulated. This implied the assumption that the amino acid supply from the diet was not limiting, which was not the case when the portal-drained viscera release of amino acids available to muscle tissues were transported as free amino acids either i) in plasma or ii) in whole blood. Consequently, the plasma or whole blood flows and amino acid extraction ratios were taken into account. The quantity of each amino acid extracted was compared with the amino acid requirements for a daily gain calculated according to the balance between the total $\mathrm{N}$ supply and the $\mathrm{N}$ requirement. With the plasma values, the daily allowed gain was $960 \mathrm{~g}$ for a $310 \mathrm{~kg}$ animal. A larger quantity of essential amino acids was taken up compared to their requirements because of the necessity of balancing the $\mathrm{N}$ released mainly by GIn and Ala. Consequently, no amino acid became limiting. For the blood values, the daily gain was estimated to be $460 \mathrm{~g}$ per day for a $240 \mathrm{~kg}$ animal. Nevertheless, the requirements of Phe, Thr, Arg and Tyr were only attained if the daily gain decreased to $150 \mathrm{~g}$ per day. Consequently, some essential amino acids were determined to be limiting for growth: Phe, Thr and Arg.
From these simulations on lactating or growing cattle, the amounts of essential amino acids appeared to be limiting. However this approach was only an approximation, due to the lack of precision of most of the parameters, and the results can only be regarded as qualitative.

\section{DISCUSSION}

From this work, it can be noted that the 'Fick principle' approach, namely the combination of blood flows, amino acid concentrations and net extractions, was of limited value in determining the fate of amino acids in ruminant metabolism. However, each of these steps provided interesting results. Blood flows could be estimated between the different compartments with high residual variations. The net appearance and release of amino acids indicated high fluxes of these metabolites between organs. The integration of the two factors described above highlighted the dynamic behaviour of the amino acid fluxes in intermediary metabolism. From this work, it appeared that these exchanges could also be effectively regulated by a subsystem acting between the organs and tissues to control the partition and fates of the amino acids. The blood flows gave an indication of this partition but the actual homeorhetic agents, if they are active, were not identified and neither were their interactions. They could be important in each protein compartment.

\section{portal-drained viscera}

The amino acid fluxes in the portal-drained viscera were adequately described. The $\mathrm{PAH}$ dilution method seems a suitable technique for determining portal blood flow. A weak point in this method is, however, that it is an invasive technique requiring several permanent catheters. Less-invasive techniques, such as ultrasonic flow probes, 
seem to become unreliable with time (NB Kristensen et al, unpublished results). Another weak point was that no relationships could be proposed concerning portal blood flow for high producing dairy animals due to a lack of data. A linear increase with the level of dry matter intake or the metabolizable energy intake seemed relevant up to a certain level of blood flow. Above this level, the required flows would need a high heart rate, or an increase in vessel pressure or dilatation, and these changes would be energy consuming. The blood flows were closely correlated with dry matter intake and metabolizable energy intake. This was the only 'regulation' to be determined. Concerning the net appearance of amino acids in the portal vein, few results were available and no significant quantitative effect was observed. It must be kept in mind that net appearance represented a balance between amino acids arriving via arterial irrigation, their release or removal by tissues and their apparent absorption in the intestine. Moreover, the use of amino acids absorbed from the small intestine by portal-drained viscera was not known, and the significance of arterial amino acid supply has just begun to be investigated (MacRae et al, 1995).

In conclusion, the different metabolic phenomena were integrated into one net appearance value, which could not be separated into each contributing process. Consequently, the importance of diet or physiological state, which influences the processes related to amino acid metabolism, could not be quantitatively estimated due to the large number of effects and the small amount of data available. The whole amino acid fluxes in portal-drained viscera could be estimated depending on the level of intake, but the origin of the amino acids could not be determined precisely. Assumptions could be made to separate the effects of each process. However, the interconversions between different amino acids would then need to be measured, and this implies the simultaneous use of several labelled amino acids. Nevertheless, one advantage of net flux studies across the portal-drained viscera was that net flux takes into account at least part of the endogenous secretion of protein, eg, pancreatic secretions; the net flux was therefore adjusted to incorporate substantial effects of endogenous secretions. For the portal-drained viscera, a net quantitative approach was undertaken and some system regulation was qualitatively underlined.

\section{Liver}

In most of the published papers, liver amino acid metabolism was considered to be a passive modulator acting in series with the portal-drained viscera. The liver extracted amino acids depending on the blood flow rate and on their concentrations in the blood. There was a constant uptake ratio, which was different for each amino acid or group of amino acids. This approach considered that the liver was supplied by blood in a 'push' hypothesis. However, this assumption linked with the experimental approach seemed partly irrelevant for the liver, which is a highly active organ. Amino acid metabolization occurs on a large scale in the liver through oxidation, gluconeogenesis, the urea cycle, protein turnover and synthesis of circulating blood proteins for the whole body. This was observed particularly clearly in our work through the high quantities of amino acids taken up for ureogenesis, but it was difficult to determine which amino acids were used for this purpose, either directly as Arg or Orn or indirectly via transamination.

An alternative method, replacing the 'black box' approach for studying amino acid metabolism, seemed technically difficult however, since the different nutrients are profoundly interrelated in the liver (Danfær, 1994). A preliminary attempt was made by Freetly et al (1993) to develop a mechanis- 
tic model of liver metabolism in which they underlined the studies required to understand the partition of nutrients in the liver. Blood flows were determined with the same precision as for the portal-drained viscera and had the same drawbacks concerning high producing dairy cows. This study was limited by the small number of observations and their accuracy relating to problems associated with amino acid analysis. Consequently, the net hepatic uptake of amino acids could not be determined in all situations. Large variations were observed, but they could not be related to hormonal regulation or nutrient availability. Thus, to be of value, experiments studying the liver should either investigate the metabolism, not only of the amino acids, but also of all the energy releasing nutrients and hormones, or they should trace the fate of key liver metabolites such as urea or $\mathrm{NH}_{3}$, by the use of labelled metabolites as it has been done by Lobley et al (1995). Liver metabolism underlines the fact that protein and energy metabolism cannot be considered separately and that the complexity of regulation must be studied and clarified in order to explain the fate of amino acids in the liver (Danfær, 1994).

\section{Muscle tissues}

To represent amino acid metabolism in muscle tissues, the model used was the hindlimb preparation. Several drawbacks are related to this preparation. The first one is that the hindlimb consists of a mixture of various tissues each having a different protein metabolism. Technically, this method is highly dependent on the position of the catheters. Consequently, the blood flow and amino acid extractions are variable depending on the experimental setup. These differences raised the question of the validity of pooling data from different publications when not all the technical biases are taken into account. This seemed to be particularly the case for the blood flow determinations which varied with the protein content of the diet and with the level of exercise of the animal. However, when the data were put together only a body weight effect was found to be significant.

The approach of Oddy and coworkers (1981) to calculate a relative blood flow (by $100 \mathrm{~g}$ of wet muscle tissue) seems interesting. A further step was to calculate the size of the muscle compartment and to obtain the absolute amino acid fluxes to and from this compartment. Net amino acid extraction ratios represent the balance between the uptake for protein gain and amino acid metabolism and the release after the degradation processes, ie, the $\mathrm{N}$ transport to the liver with Ala, Gln, Asn as carriers and some transaminations. No real effect could therefore be quantified. Labelled amino acid studies are needed to try to separate these extraction ratios into their different components. Estimates could not be made without making large assumptions. For example, the values of the amino acid extraction ratios were calculated either for plasma or for whole blood, highlighting the necessity of choosing either plasma or blood as amino acid carriers. Even though the published data gave results of a certain order of magnitude they were not consistent. Large discrepancies remained between the plasma and blood-extracted quantities, a problem that was already considered in the simulation step. This analytical bias reduced the possibility of using these values for different animals and diets especially for lactating animals, for which no data were available. Finally, homeorhetic regulation linked to the lactation could not be estimated.

\section{Mammary gland}

As judged from the quantity of data available, the mammary gland was the most examined 
organ. However, the applicability of the results obtained remains limited. First of all, the blood flow was often determined by invasive techniques, which may interfere with measurement. An indirect method was used but it did not give consistent results (Cant et al, 1993); the principle of avoiding any surgery on the cow is sound, but the assumption concerning the Phe and Tyr transfer into milk protein seemed to be too critical. An important problem is that no model was able to describe the situation for high-producing cows due to the lack of published data for these animals. This highlighted the need to extend the use of statistical models that are fitted for a certain range of values of independent parameters (here $0-30 \mathrm{~L} /$ day) up to $50 \mathrm{~L} /$ day. A second limitation was that amino acid extraction ratios varied greatly. However, no factors related to milk protein content or protein production could adequately explain these variations. As a consequence, the 'pull' hypothesis (Knight et al, 1994) received support, but the driving force for this extraction could not be identified in the present study. It could be a component in the milk, a hormonal factor at the local or whole body level, or a combination of these factors. These different possibilities emphasized the weakness of our statistical models.

In conclusion, the mammary gland amino acid uptake seemed to be regulated by the physiological state as well as being passively determined by the blood flow rate. A simultaneous study of hormone concentrations in the blood, together with amino acid extraction from the different blood compartments and their appearance in milk protein, could be an interesting approach in the future, following up on the work of Backwell et al (eg, Backwell, 1994) and Tesseraud et al (1992). A better understanding of the different steps between amino acid transport in the mammary cells and milk protein release systems, as well as their regulation, should help to clarify between the 'pull' and 'push' hypotheses.

\section{Amino acid transport in the blood}

No quantitative theory was found for amino acid transport in blood. Most of the authors considered free amino acids in the plasma as being indicative of the amino acids available for tissues and organs. However, for each protein compartment considered in our work it was demonstrated that the amino acids and small peptides in the plasma as well as those attached to the erythrocytes are taken up or released by several tissues (Backwell, 1994). This would support the results of our simulations which indicated unbalanced situations only if the plasma free amino acids were taken into account. Extensive studies of the different organs and tissues must be undertaken to quantitatively evaluate the importance of the different amino acid carriers in the blood. This could help to define reasonable laws of uptake or release by the protein compartments related to quantitative dietary factors and physiological states of the animals.

\section{Regulations of the transport and partition of amino acids}

The study of inter-organ amino acid exchanges could help to define the operating subsystem of amino acid metabolism (Sauvant, 1994). A regulated subsystem, however, needs to be clarified to predict short term (homeostasis) and long term (homeorhesis) regulation. Some qualitative effects of hormones were studied, but were not quantified. They could be considered to be the first step towards the construction of a model describing the homeorhetic control of animal (growth, lactation, gestation) or short-term needs (transient over- or undernutrition). The authors are not aware of an attempt to build a regulation for the partition of individual amino acids. This would be necessary in order to be able to predict the production of amino acids products like milk protein or muscular fibre by each tis- 
sue or organ. It seems difficult, however, to attain this goal due to the lack of knowledge about the rules concerning the amino acids and the strong interactions between the various driving factors.

Animal amino acid metabolism should be considered as a set of complex processes in a dynamic system. This work outlines some aspects of this highly active system. However, gaps in existing quantitative knowledge appeared within the different phenomena. Consequently, even if an integrated approach seemed relevant, large assumptions would need to be made if a model based on this work is to function. Some features have nevertheless been underlined. The first was that the factorial approach, which considers a constant requirement by the whole animal for maintenance and a strict separation between the needs for maintenance and production, did not seem to be directly applicable for amino acids. The differing amino acid composition and metabolism of the various tissues supported this conclusion. This was observed by Rulquin et al (1993) when they implemented the PDI system with Lys and Met. They also observed curvilinear responses in milk and protein production with increasing supply of these two amino acids. This is one indicator of the complex interactions at play. The intermediary amino acid metabolism is very stable, but significant variations can be observed after marginal increase of the input. This review also noted the agonistic and antagonistic behaviour of organs and tissues depending on their priority in the whole animal metabolism. The liver seemed to take up a large proportion of the amino acids which were consequently not available for milk protein synthesis. However, with its high uptake ratio, the mammary gland is a highly competitive organ for amino acid utilization. An initial conclusion was that the liver and mammary gland competed for some common nutrients, eg, amino acids. However, this approach excluded the peptides and the blood-cellbound amino acids which could be released by the liver and then made available for peripheral tissues. This antagonism should be studied further.

For the muscle tissues, the only available data were from growing animals. In these animals, the muscles took up a large quantity of essential amino acids. This was not the case for essential amino acids at the beginning of lactation. Some questions are raised, however, with the work of Meijer et al (1995) when they demonstrated that Gln can be limiting for milk synthesis due to its high utilization in the muscles in the lactating cow. This supports the need for the integration of a whole intermediary amino acid metabolism in a set of experiments with lactating cows to examine the dynamic competition between organs and tissues.

\section{CONCLUSION}

By pooling a large number of data, statistical relations could be calculated. Their limitations should be kept in mind, ie, they can only be used in the range of the fitted observations, including the species and physiological status. In the present effort most of the presented relationships were for one species. Limitations also arose from the technical and analytical problems associated with the determination of the parameters concerning intermediary metabolism. This study stressed the fact that nearly no quantitative regulation is known regarding the fates of amino acids in the organism, and that most of the data should be considered as semi-quantitative. The importance of monitoring several nutrients and hormones at the same time in experiments characterizing regulatory systems, has been highlighted. The definition of a regulated subsystem aimed at predicting the production of either meat or milk protein is needed 
and a concerted action should be planned to eliminate the gaps in our knowledge indicated in this work. Along the same lines, future feed evaluation systems should integrate elements of both energy and amino acid metabolism due to the significant interactions between these metabolites as reported by Danfær (1979).

\section{ACKNOWLEDGMENTS}

We thank P Williams, director of research and JC Robert, director of ruminant research and development at Rhône Poulenc Animal Nutrition for their financial and scientific support, and for their helpful advice during this project. The authors acknowledge $A$ and $C$ Ponter for correcting our written English.

\section{REFERENCES}

Ahmed B, Bergen W, Ames N (1983) Effect of nutritional state and insulin on hind-limb amino acid metabolism in steers. J Nutr 113, 1529-1543

Ahrar M, Schingoethe DJ (1979) Heat-treated soybean meal as a protein supplement for lactating cows. $J$ Dairy Sci62, 932-940

Andrew SM, Waldo DR, Erdman RA (1994) Direct analysis of body composition of dairy cows at three physiological stages. J Dairy Sci 77, 3022-3033

Annison EF, Bickerstaffe R, Linzell JL (1974) Glucose and fatty acid metabolism in cows producing milk of low fat content. J Agric Sci Camb 82, 87-95

Armentano LE (1994) Impact of metabolism by extragastrointestinal tissues on secretory rate of milk proteins. J Dairy Sci 77, 2809-2820

Austin CL, Schingoethe DJ, Casper DP, Cleale RM (1991) Influence of bovine somatotropin and nutrition on production and composition of milk from dairy cows. J Dairy Sci 74, 3920-3932

Backwell FRC (1994) Peptide utilization by tissues: current status and applications of stable isotope procedures. Proc Nutr Soc 53, 457-464

Baird GD, Symonds HW, Ash R (1975) Some observations on metabolite production and utilization in vivo by the gut and liver of adult dairy cows. J Agric Sci Camb 85, 281-296

Baldwin RL, France J, Gill M (1987) Metabolism of the lactating cow. I. Animal elements of a mechanistic model. J Dairy Res 54, 77-105
Ballard FJ, Filsell OH, Jarrett IG (1976) Amino acid uptake and output by the sheep hind limb. Metabolism 24, 415-418

Baumrucker CR (1985) Amino acid transport systems in bovine mammary tissue. J Dairy Sci 68, 2436-2451

Bell AW, Gardner JW, Manson W, Thompson GE (1975) Acute cold exposure and the metabolism of blood glucose, lactate and pyruvate, and plasma amino acids in the hind leg of the fed and fasted young ox. Br J Nutr 33, 207-217

Bequette BJ, Backwell FRC, Dhanoa MS, Walker A, Calder AG, Wray-Cahen D, Metcalf JA, Sutton JD, Beever DE, Lobley GE, MacRae JC (1994) Kinetics of blood free and milk casein-amino acid labelling in the dairy goat at two stages of lactation. Br J Nutr $72,211-220$

Bernard L, Rémond D (1995) Effect of two methods of deproteinization on the estimation of peptide bound amino acid in whole blood or plasma. In: Proceedings of the VIIth Symposium on Protein Metabolism and Nutrition, Estacao zootecnica nacional, Portugal, $p$ 139

Bickerstaffe R, Annison EF, Linzell JL (1974) The metabolism of glucose, acetate, lipids and amino acids in lactating dairy cows. $J$ Agric Sci Camb 82, 71-85

Biolo G, Tessari P, Inchiostro S, Bruttomesso D, Fongher C, Sabadin L, Fratton MG, Valerio A, Tiengo A (1992) Leucine and phenylalanine kinetics during mixed meal ingestion: a multiple tracer approach. $A m J$ Physiol 262, E455-E463

Bird AR, Chandler KD, Bell AW (1981) Effect of exercise and plane of nutrition on nutrient utilization by the hind limb of the sheep. Aust J Biol Sci 34, 541-550

Block E, Muller LD, Griel LC Jr, Garwood DL (1981) Brown midrib-3 corn silage and heat extruded soybeans for early lactating cows. J Dairy Sci $64,1813-$ 1825

Boisclair YR, Bell AW, Dunshea FR, Harkins M, Bauman DE (1993a) Evaluation of the arterio-venous difference technique to simultaneously estimate protein synthesis and degradation in the hindlimb of fed and chronically underfed steers. J Nutr 123, 10761088

Boisclair YR, Bell AW, Bauman DE (1993b) Chronic catheterization of external iliac vessels in growing cattle. J Appl Physiol 74, 444-449

Boisclair YR, Bauman DE, Bell AW, Dunshea FR, Harkins M (1994) Nutrient utilization and protein turnover in the hindlimb of cattle treated with bovine somatotropin. J Nutr 124, 664-673

Britton R, Krehbiel C (1993) Nutrient metabolism by gut tissues. J Dairy Sci 76, 2125-2131

Brockman RP, Bergman EN, Joo PK, Manns JG (1975) Effects of glucagon and insulin on net hepatic metabolism of glucose precursors in sheep. $A m J$ Physiol 229, 1344-1350 
Brown J, Crompton LA, Lomax MA (1991) Effects of isoproterenol infusion on the hindlimb metabolism of growing wether lambs. Res Vet Sci 50, 112-115

Burrin DG, Ferrell CL, Eisemann JH, Britton RA (1991) Level of nutrition and splanchnic metabolite flux in young lambs. J Anim Sci 69, 1082-1091

Cant JP (1995) Modelling uptake of blood metabolites by the mammary gland of a lactating cow. In: Proceedings of the IVth International Workshop on Modelling Nutrient Utilisation in Farm Animals (A Danfær, $P$ Lescoat, eds), National Institute of Animal Science, Denmark, 53-63

Cant JP, DePeters EJ, Baldwin RL (1993) Mammary amino acid utilization in dairy cows fed fat and its relationship to milk protein depression. J Dairy Sci 76, 762-774

Casper DP, Schingoethe DJ (1988) Protected methionine supplementation to a barley-based diet for cows during early lactation. J Dairy Sci 71, 164-172

Casper DP, Schingoethe DJ, Yang CMJ, Mueller CR (1987) Protected methionine supplementation with extruded blend of soybeans and soybean meal for dairy cows. J Dairy Sci 70, 321-330

Casper DP, Schingoethe DJ, Eisenbeisz WA (1990) Response of early lactation cows to diets that vary in ruminal degradability of carbohydrates and amount of fat. J Dairy Sci 73, 425-444

Casse EA, Rulquin H, Huntington GB (1994) Effect of mesenteric vein infusion of propionate on splanchnic metabolism in primiparous holstein cows. J Dairy Sci 77, 3296-3303

Chang TW, Goldberg AL (1978) The metabolic fates of amino acids and the formation of glutamine in skeletal muscle. J Biol Chem 253, 3685-3695

Christensen HN (1990) Role of amino acid transport and countertransport in nutrition and metabolism. Physiol Rev 70, 43-77

Clark JH (1975) Lactational responses to postruminal administration of proteins and amino acids. J Dairy Sci58, 1178-1197

Clark JH, Davis CL, Hatfield EE (1974) Effects of formaldehyde treated soybean meal on nutrient use, milk yield and composition, and free amino acids in the lactating bovine. J Dairy Sci 57, 10311036

Clark JH, Derrig RG, Davis CL, Spires HR (1975) Metabolism of arginine and ornithine in the cow and rabbit mammary tissue. $J$ Dairy Sci $58,1808-$ 1813

Crompton LA, Lomax MA (1993) Hindlimb protein turnover and muscle protein synthesis in lambs: a comparison of techniques. Br J Nutr 69, 345-358

Danfær A (1979) Quantitative protein and energy metabolism in a high-yielding dairy cow. In: Protein Utilization In Farm Animals. Vol II, Institute of Animal Science, The Royal Veterinary and Agricultural University, Copenhagen, 44
Danfær A (1990) A dynamic model of nutrient digestion and metabolism in lactating dairy cows. Thesis, Report 671, National Institute of Animal Science, Foulum, 511

Danfær A (1994) Nutrient metabolism and utilization in the liver. Livest Prod Sci 39, 115-127

Danfær A, Tetens V, Agergaard N (1995) Review and an experimental study on the physiological and quantitative aspects of gluconeogenesis in lactating ruminants. Comp Biochem Physiol 111B, 201-210

Danilson DA, Webb KE Jr, Herbein JH (1987a) Transport and hindlimb exchange of plasma and blood-cell amino acids in calves fed soy- or urea-based purified diets. J Anim Sci64, 1842-1851

Danilson DA, Webb KE Jr, Herbein JH (1987b) Transport and hindlimb exchange of peptide and serum amino acids in calves fed soy- or urea-based purified diets. J Anim Sci 64, 1852-1857

Davis SR, Collier RJ, McNamara JP, Head HH, Sussman $W(1988)$ Effects of thyroxine and growth hormone treatment of dairy cows on milk yield, cardiac output and mammary blood flow. J Anim Sci66, 70-79

Derrig RG, Clark JH, Davis CL (1974) Effect of abomasal infusion of sodium caseinate on milk yield, nitrogen utilization and amino acid nutrition of the dairy cow. J Nutr 104, 151-159

Dhondt G, Houvenaghel A, Peeters G, Verschooten F (1973) Influence of hormones on blood flow through the mammary artery in lactating cows. J Arch int Pharmacodyn Ther 204, 89-104

Drackley JK, Schingoethe DJ (1986) Extruded blend of soybean meal and sunflower seeds for dairy cattle in early lactation. J Dairy Sci 69, 371-384

Early RJ, Thompson JR, Christopherson RJ, Sedgwick GW (1987) Blood branched-chain amino and $\rightarrow$ keto acid concentrations and net exchange across the portal-drained viscera and hindlimb of fed and fasted ruminants. Can J Anim Sci 67, 1011-1020

Early RJ, McBride BW, Ball RO (1988) Phenylalanine metabolism in sheep infused with glucose plus insulin. I. Effects on plasma phenylalanine concentration, entry rate and utilization by the hindlimb. Can $J$ Anim Sci 68, 711-719

Eisemann JH, Nienaber JA (1990) Tissue and wholebody oxygen uptake in fed and fasted steers. $B r J$ Nutr 64, 399-411

Eisemann $\mathrm{JH}$, Huntington $\mathrm{GB}$ (1994) Metabolic flux across portal-drained viscera, liver, and hindquarters of hyperinsulinemic, euglycemic beef steers. $J$ Anim Sci 72, 2919-2929

Eisemann JH, Huntington GB, Ferre!l CL (1987) Blood flow to hindquarters of steers measured by transit time ultrasound and indicator dilution. $J$ Dairy $S c i$ $70,1385-1390$

Eisemann JH, Huntington GB, Ferrell CL (1988) Effects of dietary clenbuterol on metabolism of the hindquarters in steers. J Anim Sci 66, 342-353 
Erickson PS, Murphy MR, Clark JH (1992) Supplementation of dairy cows diets with calcium salts of longchain fatty acids and nicotinic acid in early lactation. $J$ Dainy Sci 75, 1078-1089

Freetly HC, Knapp JR, Calvert CC, Baldwin RL (1993) Development of a mechanistic model of liver metabolism in the lactating cow. Agric Sys 41, 157 195

Gross KL, Harmon DL, Avery TB (1988) Net portal nutrient flux in steers fed diets containing wheat and sorghum grain alone or in combination. J Anim Sci $66,543-551$

Guerino F, Huntington GB, Erdman RA (1991) The net portal and hepatic flux of metabolites and oxygen consumption in growing beef steers given postruminal casein. J Anim Sci69, 387-395

Guinard J, Rulquin H (1994) Effect of graded levels of duodenal infusions of casein on mammary uptake in lactating cows. 2. Individual amino acids. J Dairy Sci 77, 3304-3315

Guinard J, Rulquin H, Vérité R (1994) Effect of graded levels of duodenal infusion of casein on mammary uptake in lactating cows. 1. Major nutrients. J Dairy Sci 77, 2221-2231

Hadsell DL, Sommerfeldt JL (1988) Chickpeas as a protein and energy supplement for high producing dairy cows. J Dairy Sci 71, 762-772

Hammond AC, Huntington GB, Reynolds PJ, Tyrell HF, Eisemann JH (1987) Absorption, plasma flux and oxidation of L-Leucine in heifers at two levels of intake. J Anim Sci 64, 420-425

Hanigan MD, Calvert CC, DePeters EJ, Reis BL, Baldwin RL (1991) Whole blood and plasma amino acid uptakes by lactating bovine mammary glands. J Dairy Sci 74, 2484-2490

Hanigan MD, Calvert CC, DePeters EJ, Reis BL, Baldwin RL (1992) Kinetics of amino acid extraction by lactating mammary glands in control and sometribove-treated holstein cows. J Dairy Sci 75, 161173

Harmon DL, Avery TB, Huntington GB, Reynolds PJ (1988) Influence of ionophore addition to roughage and high-concentrate diets on portal blood flow and net nutrient flux in cattle. Can J Anim Sci 68, 419429

Harmon DL, Kreikemeier KK, Gross KL (1993) Influence of addition of monensin to an alfalfa hay diet on net portal and hepatic nutrient flux in steers. J Anim Sci $71,218-225$

Harper AE, Miller RH, Block KP (1984) Branched-chain amino acid metabolism. Ann Rev Nutr 4, 409-454

Hartmann PE, Kronfeld DS (1973) Mammary blood flow and glucose uptake in lactating cows given dexamethasone. J Dairy Sci 56, 896-902

Heitmann RN, Sensenig SC, Reynolds CK, Fernandez JM, Dawes DJ (1986) Changes in energy metabolite and regulatory hormone concentrations and net fluxes across spianchnic and peripheral tissues in fed and progressively fasted ewes. J Nutr 116, 25162524

Huber JT, Emery RS, Bergen WG, Liesman JS, Kung L Jr, King KJ, Gardner RW, Checketts M (1984) Influences of methionine hydroxy analog on milk fat production, blood serum lipids, and plasma amino acids. $J$ Dairy Sci 67, 2525-2531

Hume ID, Jacobson DR, Mitchell GE (1972) Quantitative studies on amino acid absorption in sheep. $J$ Nutr $102,495-506$

Huntington GB (1982) Portal blood flow and net absorption of ammonia-nitrogen, urea-nitrogen, and glucose in non-lactating holstein cows. J Dairy Sci 65 , 1155-1162

Huntington GB (1984) Net absorption of glucose and nitrogenous compounds by lactating holstein cows. J Dairy Sci 67, 1919-1927

Huntington GB (1987) Net absorption from portal-drained viscera of nitrogenous compounds by beef heifers fed on diets differing in protein solubility or degradability in the rumen. Br J Nutr 57, 109-114

Huntington GB (1990) Energy metabolism in the digestive tract and liver of cattle: Influence of physiological state and nutrition. Reprod Nutr Dev 30, 35-47

Huntington GB, Prior RL (1983) Digestion and absorption of nutrients by beef heifers fed a high concentrate diet. J Nutr 113, 2280-2288

Huntington GB, Prior RL (1985) Net absorption of amino acids by portal-drained viscera and hind half of beet cattle fed a high concentrate diet. J Anim Sci 60 , 1491-1499

Huntington GB, Reynolds PJ, Tyrell HF (1983) Net absorption and ruminal concentration of metabolites in non-pregnant dry holstein cows before and after intraruminal acetic acid infusion. J Dairy Sci66, 19011908

Huntington GB, Varga GA, Glenn BP, Waldo DR (1988) Net absorption and oxygen consumption by holstein steers fed alfalfa or orchardgrass silage at two equalized intakes. J Anim Sci 66, 1292-1302

Huntington GB, Eisemann JH, Whitt JM (1990) Portal blood flow in beef steers: comparison of techniques and relation to hepatic blood flow, cardiac output and oxygen uptake. J Anim Sci 68, 1666-1673

Hvelplund T, Madsen J (1990) A study of the quantitative nitrogen metabolism in the gastro-intestinal tract, and the resulting new protein evaluation system for ruminants. The AAT-PBV system. Thesis Institute of Animal Science, The Royal Veterinary and Agricultural University, Copenhagen, 215

IIIg DJ, Sommerfeldt JL, Schingoethe DJ (1987) Lactational and systemic responses to the supplementation of protected methionine in soybean meal diets. J Dairy Sci 70, 620-629

INRA (1988) Alimentation des bovins, ovins, caprins ( $R$ Jarrige, ed). INRA, France 
Isserty A, Ortigues I (1994) Méthodes d'exploitation des données concernant les débits sanguins au niveau des viscères et du train-arrière chez la brebis. Reprod Nutr Dev 34, 399-413

Jungas RL, Halperin ML, Brosnan JT (1992) Quantitative analysis of amino acid oxidation and related gluconeogenesis in humans. Physiol Rev 72, 419-448

Katz ML, Bergman EN (1969) Simultaneous measurements of hepatic and portal venous blood flow in the sheep and dog. Am J Physiol 216, 946-952

Kellaway RC, Ranawana SSE, Buchanan JH, Smart LD (1974) The effect of nitrogen source in the diet on the milk production and amino acid uptake by the udder. $\checkmark$ Dairy Res 41, 305-315

Kensinger MH, Collier RJ, Wilcox CJ, Caton D (1983) Variety of resting mammary blood flow in non-lactating holstein cows. J Dairy Sci 66, 1742-1746

King KJ, Huber JT, Sadik M, Bergen WG, Grant AL, King VL (1990) Influence of dietary protein sources on the amino acid profiles available for digestion and metabolism in lactating cows. J Dairy Sci 73, 32083216

Klusmeyer TH, Clark JH, Vicini JL, Murphy MR, Fahey GC Jr (1987) Effects of feeding or infusing ammonium salts of volatile fatty acids on ruminal fermentation, plasma characteristics, and milk production of cows. J Dairy Sci 70, 50-63

Knight CH, France J, Beever DE (1994) Nutrient metabolism and utilization in the mammary gland. Liv Prod Sci 39, 129-137

Koeln LL, Schlagheck TG, Webb KE (1993) Amino acid flux across the gastrointestinal tract and liver of calves. J Dairy Sci 76, 2275-2285

Krehbiel CR, Harmon DL, Schnieder JE (1992) Effects of increasing ruminal butyrate on portal and hepatic nutrient flux in steers. J Anim Sci 70, 904-914

Kreikemeier KK, Harmon DL, Brandt RT Jr, Avery TB, Johnson DE (1991) Small intestinal starch digestion in steers: effect of various levels of abomasal glucose, corn starch and corn dextrin infusion on small intestine disappearance and net glucose absorption. J Anim Sci 69, 328-338

Kronfeld DS, Raggi F, Ramberg CF Jr (1968) Mammary blood flow and ketone body metabolism in normal, fasted and ketotic cows. Am J Physiol 215, 218-227

Laarveld B, Christensen DA, Brockman RP (1981) The effect of insulin on net metabolism of glucose and amino acids by the bovine mammary gland. Endocrinology 108, 2217-2221

Lanham JK, Coppock CE, Brooks KN, Wilks DL, Horner $\mathrm{JL}$ (1992) Effects of whole cottonseed or niacin or both on casein synthesis by lactating holstein cows. J Dairy Sci 75, 184-192

Lescoat $P$, Sauvant D (1994) Amino acid uptake predictions in the mammary gland of the lactating cows. Proc Soc Nutr Physiol 3, 238
Lescoat $P$, Sauvant D (1995) Development of a mechanistic model for rumen digestion validated using the duodenal flux of amino acids. Reprod Nutr Dev $35,45-70$

Linzell JL (1974) Mammary blood flow and methods of identifying and measuring precursors of milk. In: Lactation, a Comprehensive Treatise (BL Larson, VR Smith, eds), 143-226

Lobley GE, Connell A, Lomax MA, Brown DS, Milne E, Calder AG, Farningham DAH (1995) Hepatic detoxification of ammonia in the ovine liver: possible consequences for amino acid catabolism. Br J Nutr 73 , 667-685

Lomax MA, Baird GD (1983) Blood flow and nutrient exchange across the liver and gut of the dairy cow. Effects of lactation and fasting. $B r J$ Nutr 49,481 496

Lough DS, Beede DL, Wilcox CJ (1990) Effects of feed intake and thermal stress on mammary blood flow and other physiological measurements in lactating dairy cows. J Dairy Sci 73, 325-332

MacRae JC, Backwell FRC, Bequette BJ, Lobley GE (1995) Protein metabolism in specific tissues. In: Proceedings of the VIlth Symposium on Protein Metabolism and Nutrition, Estacao zootecnica nacional, Portugal, $\mathrm{p} 98$

McCormick ME, Webb KE (1982) Plasma free, erythrocyte free and plasma peptide amino acid exchange of calves in steady state and fasting metabolism. $J$ Nutr 112, 276-282

McGuire MA, Beede DK, DeLorenzo MA, Wilcox CJ, Huntington GB, Reynolds CK, Collier RJ (1989) Effects of thermal stress and level of feed intake on portal plasma flow and net fluxes of metabolites in lactating holstein cows. J Anim Sci 67, 1050-1060

Meijer GAL, van der Meulen J, Bakker JGM, van der Koelen CJ, van Vuuren AM (1995) Free amino acids in plasma and muscle of high yielding dairy cows in early lactation. J Dairy Sci 78, 1131-1141

Metcalf JA, Sutton JD, Cockburn JE, Napper DJ, Beever DE (1991) The influence of insulin and amino acid supply on amino acid uptake by the lactating bovine mammary gland. J Dairy Sci 74, 3412-3420

Mineo $H$, Yasuda $T$, Akiyama $M$, Oyamada $T$, Kato $S$, Ushijima J (1991) Effect of feeding on hepatic and portal blood flow in sheep. Small Ruminant Res 5 , 181-186

Moore AJ (1985) A mathematical equation for animal growth from embryo to adult. Anim Prod 40, 441-453

Munneke RL, Schingoethe DJ, Casper DP (1991) Lactation evaluation of ruminally protected methionine in diets containing extruded soybeans and urea. J Dairy Sci 74, 227-233

Neutze SA, Oddy VH, Gooden JM (1994) A cranial mesenteric vein preparation for measurement of amino acid uptake by lambs. J Agric Sci (Camb) $122,309-314$ 
O'Connor J, Sniffen C, Fox D, Chalupa W (1993) A net carbohydrate and protein system for evaluating cattle diet. IV. Predicting amino acid adequacy. I Anim Sci 71, 1298-1311

Oddy VH, Brown BW, Jones AW (1981) Measurement of organ blood flow using tritiated water. I. Hind limb muscle blood flow in conscious ewes. Aust $J$ Biol Sci 34, 419-425

Oddy VH, Lindsay DB, Barker PJ, Northrop AJ (1987) Effect of insulin on hind-limb and whole-body leucine and protein metabolism in fed and fasted lambs. $\mathrm{Br}$ J Nutr 58, 437-452

Ohara I, Ariyoshi S (1979) Comparison of protein precipitants for the determination of free amino acids in plasma. Agric Biol Chem 43, 1473-1478

Ortigues I (1991) Adaptation du métabolisme énergétique des ruminants à la sous-alimentation. Quantification au niveau de l'animal entier et de tissus corporels. Reprod Nutr Dev 31, 593-616

Peeters G, Houvenaghel A, Roets E, Massart-Leën AM, Verbeke R, Dhondt G, Verschooten F (1979) Electromagnetic blood flow recording and balance of nutrients in the udder of lactating cows. J Anim Sci $48,1143-1153$

Pethick DW, Vernau B (1984) The effect of acetate on the utilization of glucose by skeletal muscle of the sheep hindlimb. Can J Anim Sci 64 (Suppl), 291-292

Pethick DW, Lindsay DB, Barker PJ, Northrop AJ (1981) Acetate supply and utilization by the tissues of sheep in vivo. Br J Nutr 46, 97-110

Pethick DW, Harman N, Chong JK (1987) Non-esterified long-chain fatty acid metabolism in fed sheep at rest and during exercise. Aust J Biol Sci 40, 221-234

Pocius PA, Clark JH, Baumrucker CR (1981) Glutathione in bovine blood: possible source of amino acids for milk protein synthesis. J Dainy Sci 64,1551 1554

Prewitt LR, Jacobson DR, Hemken RW, Schelling GD, Hatton $\mathrm{RH}$ (1975) Amino acid absorption by portaljuguiar venous differences in sheep fed two maturities of alfalfa hay. J Anim Sci 41, 1722-1727

Prior RL, Huntington GB, Britton RA (1981) Influence of diet on amino acid absorption in beef cattle and sheep. J Nutr 111, 2212-2222

Rasmussen $F$ (1965) The mammary blood flow in the cow as measured by the antipyrine absorption method. Acta Vet Scand 6, 135-149

Reynolds CK, Huntington GB (1988) Partition of portaldrained visceral net flux in beef steers. 1. Blood flow and net flux of oxygen, glucose and nitrogenous compounds across stomach and post-stomach tissues. Br J Nutr 60, 539-551

Reynolds CK, Tyrrell HF (1991) Effects of mesenteric vein L-Alanine infusion on liver metabolism in beef heifers fed on diets differing in forage:concentrate ratio. Br J Nutr $66,437-450$
Reynolds M, Linzell JL, Rasmussen F (1968) Comparison of four methods for measuring mammary blood flow in conscious goats. Am J Physiol 214, 1415-1424

Reynolds CK, Huntington GB, Tyrell HF, Reynolds PJ (1988) Net portal-drained visceral and hepatic metabolism of glucose, L-lactate, and nitrogenous compounds in lactating holstein cows. $J$ Dairy Sci $71,1803-1812$

Reynolds CK, Tyrrell HF, Reynolds PJ (1991) Effects of diet forage-to-concentrate ratio and intake on energy metabolism in growing beef heifers: whole body energy and nitrogen balance and visceral heat production. J Nutr 121, 994-1003

Reynolds CK, Lapierre H, Tyrrell HF, Elsasser TH, Staples RC, Gaudreau P, Brazeau P (1992) Effects of growth hormone-releasing factor and feed intake on energy metabolism in growing beef steers: net nutrient metabolism by portal-drained viscera and liver. $J$ Anim Sci 70, 752-763

Reynolds CK, Harmon DL, Cecava MJ (1994a) Absorption and delivery of nutrients for milk protein synthesis by portal-drained viscera. J Dairy Sci 77, 2787-2808

Reynolds CK, Harmon DL, Prior RL, Tyrrell HF (1994b) Effects of mesenteric vein L-alanine infusion on liver metabolism of organic acids by beef heifers fed diets differing in forage:concentrate ratio. J Anim Sci 72, 3196-3206

Riis P (1983) Dynamic Biochemistry of Animal Production World Animal Science A3. Elsevier Science, Amsterdam, The Netherlands $p 76$

Rulquin H (1987) Détermination de certains acides aminés limitants chez la vache laitière par la méthode des infusions post-ruminales. Reprod Nutr Dev 27 (1B), 299-300

Rulquin H, Pisulewski PM, Vérité R, Guinard J (1993) Milk production and composition as a function of postruminal lysine and methionine supply: a nutrient-response approach. Livest Prod Sci 37, 69-90

Saporta G (1990) Probabilités analyse des données et statistiques. Éditions Technip, Paris

Sauvant D (1994) Modelling homeostatic and homeorhetic regulation in lactating animals. Livest Prod Sci 39, 105-113

SAS User's Guide: Statistics, Version 6 Edition (1987) SAS Inst, Inc, Cary, NC

Seal CJ, Parker DS, Avery PJ (1992) The effect of forage and forage-concentrate on rumen fermentation and metabolism of nutrients by the mesenteric and portal-drained viscera in growing steers. Br J Nutr 62, 355-370

Seymour WM, Polan CE, Herbein JH (1990) Effects of dietary protein degradability and casein or amino acid infusions on production and plasma amino acid in dairy cows. J Dairy Sci 73, 735-748

Skórko-Sajko H, Hvelplund T, Weisbjerg MR (1994) Rumen degradation and intestinal digestibility of 
amino acids in different roughages estimated by nylon bag techniques. J Anim Feed Sci 3, 1-10

Smith NE, Baldwin RL (1974) Effects of breed, pregnancy, and lactation on weight of organs and tissues in dairy cattle. $J$ Dairy Sci $57,1055-1060$

Sniffen CJ, Jacobson DR (1975) Net amino acid absorption in steers fed alfalfa hay cut at two stages of maturity. J Dairy Sci 58, 371-385

Symonds ME, Lomax MA (1990) Effect of chronic cold exposure and underfeeding on hind-limb tissue mtabolism in pregnant sheep. J Agric Sci (Camb) $115,421-428$

Symonds ME, Bryant MJ, Shepherd DAL, Lomax MA (1988) Glucose metabolism in shorn and unshorn pregnant sheep. Br J Nutr 60, 249-263

Tagari H, Bergman EN (1978) Intestinal disappearance and portal blood appearance of amino acids in sheep. J Nutr 108, 790-803

Tamminga S, Van Straalen W, Subnel A, Meijer R, Steg A, Wever C, Blok M (1994) The Dutch protein evaluation system: the DVE/OEB-system. Liv Prod SCi $40,139-155$

Teleni E (1993) Catabolism and synthesis of amino acids in skeletal muscle: their significance in monogastric mammals and ruminants. Aust J Agric Res 44, 443461

Teleni E, Annison EF (1986) Development of a sheep hind-limb muscle preparation for metabolic studies. Aust J Biol Sci 39, 271-281

Teleni E, Annison E, Lindsay D (1986) Metabolism of valine and exchange of amino acids across the hind- limb muscles of fed and stanved sheep. Aust $J$ Biol Sci 39, 379-393

Tesseraud S, Grizard J, Makarski B, Debras E, Bayle G, Champredon C (1992) Effect of insulin in conjunction with glucose, amino acids and potassium on net metabolism of glucose and amino acids in the goat mammary gland. J Dairy Res $59,135-149$

Tomassone R, Audrain S, Lesquoy-de Turckheim E, Millier C (1992) La régression, nouveaux regards sur une ancienne méthode statistique. Masson, Paris

Vérité R, Peyraud JL (1989) Protein: the PDI systems. In: Ruminant Nutrition, Recommended Allowances and Feed Tables (R Jarrige, ed), INRA, Paris, 33-48

Waghorn GC, Baldwin RL (1984) Model of metabolite flux within mammary gland of the lactating cows. J Dairy Sci 67, 531-544

Webb KE, Matthews JC, DiRienzo DB (1992) Peptide absorption: a review of current concepts and future perspectives. J Anim Sci 70, 3248-3257

Wieghart M, Slepetis R, Elliot JM, Smith DF (1986) Glucose absorption and hepatic gluconeogenesis in dairy cows fed diets varying in forage content. $J$ Nutr $116,839-850$

Wolff JE, Bergman EN, Williams HH (1972) Net metabolism of plasma amino acids by liver and portal-drained viscera of fed sheep. Am J Physiol 223, 438-446

Yang CMJ, Schingoethe DJ, Casper DP (1986) Protected methionine and heat-treated soybean meal for high producing dairy cows. J Dairy Sci 69,2348 2357 